\title{
Perioperative Coagulation Management and Control of Platelet Transfusion by Point-of-Care Platelet Function Analysis
}

\author{
Klaus Görlinger ${ }^{a}$ Csilla Jambor ${ }^{b}$ Alexander A. Hanke ${ }^{a}$ Daniel Dirkmann \\ Matthias Hartmann ${ }^{a}$ Niels Rahe-Meyer ${ }^{\mathrm{C}}$ \\ ${ }^{a}$ Klinik für Anästhesiologie und Intensivmedizin, Universitätsklinikum Essen, \\ ${ }^{b}$ Klinik für Anästhesiologie, Intensivmedizin und Schmerztherapie, Universitätsklinikum Frankfurt am Main, \\ c Zentrum Anästhesiologie, Medizinische Hochschule Hannover, Germany
}

Michael Adamzik ${ }^{a}$

\section{Key Words}

Point-of-care coagulation management . Platelet function analysis - Impedance aggregometry .

Thrombelastometry · Cardiac surgery

\section{Summary}

Background: About one third of all blood components transfused intraoperatively is used in cardiac surgery, whereas mortality of cardiosurgical patients correlates nearly linear with the number of transfused units of packed red blood cells. Acquired platelet function disorders play a major role in perioperative bleeding in cardiac surgery. Therefore, the use of point-of-care-suitable platelet function analyzers seems to be reasonable in this field. Methods: Platelet function analyzer PFA- $100^{\circledR}$, rotational thrombelastometry $\left(\right.$ ROTEM $\left.^{\circledR}\right)$, and multiple platelet function analyzer (Multiplate ${ }^{\circledR}$ ) are in principle applicable for point-of-care testing. Since these three analyzers monitor different aspects of platelet function and have different limitations, the selection of the right test system depends on the right question. Results: Perioperative use of platelet function analyzers is helpful in prediction of blood loss in cardiac surgery. Perioperative usage of blood components and their respective costs can be reduced by an appropriate coagulation management. Conclusion: Algorithms for perioperative coagulation management based on point-of-care testing permit a fast diagnostic and goal-directed therapy of coagulation and functional platelet disorders. The possibility to reduce the mortality of patients and the overall cost for hospital stay is subject of further studies.

\begin{abstract}
Schlüsselwörter
Point-of-Care-Gerinnungsmanagement - Thrombozytenfunktionsanalyse · Impedanz-Aggregometrie · Thrombelastometrie $\cdot$ Herzchirurgie
\end{abstract}

\section{Zusammenfassung}

Hintergrund: Etwa ein Drittel aller intraoperativ verbrauchten Blutkonserven werden im Bereich der Herzchirurgie transfundiert, wobei die Mortalität kardiochirurgischer Patienten nahezu linear mit der Zahl der transfundierten Erythrozytenkonzentrate korreliert. Erworbene Thrombozytenfunktionsstörungen spielen bei perioperativen Blutungen in der Herzchirurgie eine wesentliche Rolle. Dies legt den Einsatz von Point-of-Care-tauglichen Thrombozytenfunktionsanalysatoren in diesem Bereich nahe. Methoden: Der Platelet Function Analyzer PFA$100^{\circledR}$, die Rotationsthrombelastometrie (ROTEM ${ }^{\circledR}$ ) und der Multiple Platelet Function Analyzer (Multiplate ${ }^{\circledR}$ ) sind prinzipiell für den Point-of-Care-Einsatz geeignet. Da diese 3 Analysatoren jedoch unterschiedliche Aspekte der Thrombozytenfunktion untersuchen und auch unterschiedliche Limitationen aufweisen, hängt die Auswahl des richtigen Testsystems von der jeweiligen Fragestellung ab. Ergebnisse: Der perioperative Einsatz von Thrombozytenfunktionsanalysatoren ist für die Prädiktion des Blutverlusts bei kardiochirurgischen Eingriffen hilfreich. Durch ein entsprechendes Gerinnungsmanagement lässt sich der perioperative Verbrauch an Blutprodukten und die daraus resultierenden Kosten reduzieren. Schlussfolgerungen: Auf Point-of-Care-Verfahren basierende Algorithmen zum perioperativen Gerinnungsmanagement ermöglichen eine zeitnahe Diagnostik und zielgerichtete Therapie von Gerinnungs- und Thrombozytenfunktionsstörungen. Ob dadurch auch die Mortalität der Patienten und die Gesamtkosten für den Krankenhausaufenthalt gesenkt werden können, ist Thema weiterer Untersuchungen.

\begin{tabular}{ll}
\hline KARGER & @ 2007 S. Karger GmbH, Freiburg \\
Fax +497614520714 & Accessible online at: \\
$\begin{array}{l}\text { E-mail Information@Karger.de } \\
\text { www.karger.com }\end{array}$ & www.karger.com/tmh
\end{tabular}




\section{Introduction}

In 2004, one third of all intraoperatively used blood products (packed red blood cells (PRBC), fresh frozen plasma (FFP) and platelet concentrates (PC)) have been transfused in thoracic and cardiovascular surgery at the university clinics of Essen. This finding is consistent with the literature that patients undergoing cardiac surgery are at high risk for excessive microvascular bleeding and re-exploration [1]. Laboratory evaluation of platelets and coagulation factors can facilitate the optimal administration of pharmacologic and transfusionbased therapy. However, their turnaround time makes laboratory-based methods impractical for concurrent coagulation management of patients during surgery [2]. Point-of-care (POC) tests enable contemporary and targeted therapy of coagulation disorders $[3,4]$. Coupled with algorithms for coagulation management, the use of POC tests may be able to reduce transfusion requirements, re-exploration rates and costs $[1,5,6]$.

As a result of our positive experience and a significant reduction in transfusion requirements after inauguration of a ROTEM $^{\circledR}$-based POC coagulation management scheme in the field of visceral surgery and liver transplantation in 2000, we introduced a POC coagulation management in thoracic and cardiovascular surgery in 2004 [7].

The reduction of transfusion requirements in cardiac surgery is of great importance because there is a nearly linear correlation between the mortality of cardiosurgical patients and the number of transfused PRBC [8]. Furthermore, transfusion of FFP is correlated with the risk of transfusion-related acute lung injury (TRALI) and transfusion-associated cardiocirculatory overload (TACO) [9-14]. In addition, the number of transfused PC shows a negative correlation with the outcome of cardiosurgical patients $[15,16]$. This effect seems to be reduced by leucodepletion of $\mathrm{PC}$, which by now is performed routinely in Germany and most parts of Europe [17]. However, with an incidence of $1: 1,000$ to $1: 3,000$ bacterial contamination of $\mathrm{PC}$ is the most common transfusion-associated risk of infection. Thereby, PC can induce septic complications $(1: 15,000)$ with a mortality rate of 1 per $60,000 \mathrm{PC}[9,13$, 18-20]. Therefore, the indication for platelet transfusion should be evaluated very carefully, as could be possible with the use of POC analysis of platelet function.

Whereas detection and treatment of hyperfibrinolysis and plasmatic coagulation disorders are the most important aspects of perioperative coagulation management during liver transplantation and multiple trauma, in cardiac surgery heparin effects and disorders of the primary haemostasis - such as thrombocytopenia and especially acquired platelet function disorders - are of primary importance [1, 2, 21-25]. On the other hand therapy with platelet aggregation inhibitors is of vital importance in cardiology to avoid stent thrombosis after implantation of coronary stents - especially in the context of drug-eluting stents [26]. This area of conflict has to be consid- ered in connection with the selection of the right tool for POC coagulation management.

\section{Methods for Detection of Perioperative Coagulation and Platelet Function Disorders}

\section{POC Platelet Function Tests}

Since standard methods of platelet function analysis - like Born aggregometry and flow cytometry - are subjected to specialised laboratories, because of the complexity of the tests, perioperative platelet diagnostics is limited primarily to the platelet count, and the response to platelet transfusion is monitored by calculating the platelet-corrected count increment (CCI) and by the clinical parameter 'bleeding stopped' [27-29].

Experiences and studies of the last years have shown that POC-suitable coagulation and platelet function analyzers can be helpful in detection of perioperative platelet function disorders and for decisions in context with the therapy with PC, coagulation factor concentrates, and haemostatic drugs. Furthermore, they are able to contribute to the reduction of transfusion requirements and costs [7, 30-34]. In this context, the aptitude of the following three systems has been proved particularly:

- platelet function analyzer 100 (PFA-100 ${ }^{\circledR}$; Dade-Behring, Marburg, Germany),

- rotational thrombelastometry $\left(\right.$ ROTEM $^{\circledR}$; Pentapharm GmbH, Munich, Germany),

- multiple platelet function analyzer (Multiplate ${ }^{\circledR} ;$ Dynabyte GmbH, Munich, Germany).

These three analyzers are characterized by the following features, which enables their use as POC test systems:

- usage of anticoagulated whole blood (no centrifugation required),

- usage of disposable cartridges or cups (no preparation or cleaning required),

- ease of operation (automatic electronic pipette and computer-assisted operation procedures and analysis of the data for ROTEM and Multiplate).

\section{Ask the Right Question}

Since these three analyzers monitor different aspects of platelet function and have different limitations, the selection of the right test system depends on the right question [35] (table 1):

- When shall the analysis be done?

- preoperative,

- intraoperative,

- postoperative.

- What kind of disorder shall be detected or excluded? 
Table 1. Comparison of POC methods for platelet function analysis: PFA-100, Multiplate,and ROTEM - characteristics, indications, and limitations

\begin{tabular}{llll}
\hline Platelet function analysis & PFA-100 & Multiplate & ROTEM \\
\hline Blood sample & buffered citrated whole blood & $\begin{array}{l}\text { heparin or thrombin inhibitor } \\
\text { (hirudin) whole blood }\end{array}$ & citrated whole blood \\
\hline Shear stress & high & no & low \\
\hline Stimulator & collagen/ epinephrin (PFA-EPI) & $\begin{array}{l}\text { collagen (COLtest), AA (ASPItest), } \\
\text { ADP (ADPtest),TRAP-6 (TRAPtest) } \\
\text { or collagen/ADP (PFA-ADP) }\end{array}$ & $\begin{array}{l}\text { only recalcification (NaTEM); } \\
\text { recalcification and thromboplastin } \\
\text { (tissue factor) (ExTEM); recalcification } \\
\text { and partial thromboplastin } \\
\text { (phospholipid) and ellagic acid (InTEM) }\end{array}$ \\
\hline
\end{tabular}

\begin{tabular}{|c|c|c|}
\hline Additives & no & $\begin{array}{l}\text { prostaglandin E1 (to increase } \\
\text { sensitivity for clopidogrel (ADPtest } \\
\text { HS)); ASA or tirofiban (to predict } \\
\text { therapeutical efficiency or to controll } \\
\text { patient's compliance) }\end{array}$ \\
\hline
\end{tabular}

cytochalasin D (FibTEM); aprotinin (ApTEM); heparin inhibitor (ExTEM, FibTEM and ApTEM); heparinase (HepTEM); ecarin (EcaTEM); factor VIIa, VIII, XIII, etc. (X-TEM)

Main parameters closure time (in s)

AUC (in AU $\times$ min); aggregation (in $A U)$; velocity (in AU/min) clotting time (in s); clot formation time (CFT in s); amplitude after 5/10/15 min (A5/A10/A15 in mm); maximum clot firmness (MCF in $\mathrm{mm}$ ); clot lysis index (CLI in \%)

platelet-fibrin(ogen) interaction

GPIIb/IIIa; PAR1 and PAR4

GPIIb/IIIa; GPIaIIa, P2Y12, PAR1 and PAR4
ASA and clopidogrel effects; GPIIb/IIIa receptor inhibitors (linearity within the therapeutic range); platelet function $\begin{array}{ll}\text { pool disease; ASA effects } & \text { range); p } \\ \text { ( }>7 \text { days); GPIIb/IIIa receptor } & \text { disorders }\end{array}$ inhibitors (too high sensitivity!)

$\begin{array}{ll}\text { von Willebrand syndrome; } & \text { ASA and clopidogrel effects; } \\ \text { Bernard-Soulier syndrome; } & \text { GPIIb/IIIa receptor inhibitors } \\ \text { Morbus Glanzmann; Storage } & \text { (linearity within the therapeutic } \\ \text { pool disease; ASA effects } & \text { range); platelet function } \\ \text { (>7 days); GPIIb/IIIa receptor } & \text { disorders } \\ \text { inhibitors (too high sensitivity!) } & \end{array}$

ASA; clopidogrel; GPIIb/IIIa receptor inhibitors severe platelet function disorders with resistance to thrombin stimulation; fibrinogen deficiency and polymerisation disorders; hyperfibrinolysis; heparin and hirudin effects; severe coagulation factor deficiency

\section{fibrinogen substitution; platelet} transfusion; aprotinin; tranexamic acid; heparin; protamine; coagulation factor concentrates

\begin{tabular}{|c|c|c|c|}
\hline Limitations & $\begin{array}{l}\text { low sensitivity for clopidogrel } \\
\text { effects; too high sensitivity for } \\
\text { GPIIb/IIIa receptor inhibitors; } \\
\text { thrombocytopenia }<100 / \mathrm{nl} \text {; } \\
\text { anaemia with } \mathrm{Hkt}<35 \% \text { (Hb } \\
<11 \mathrm{~g} / \mathrm{dl} \text { ); flow errors because of } \\
\text { platelet aggregation during surgery }\end{array}$ & von Willebrand syndrome type I & $\begin{array}{l}\text { low sensitivity to antiplatelet drugs } \\
\text { (ASA, clopidogrel, GPIIb/IIIa receptor } \\
\text { inhibi-tors), oral anticoagulants and low } \\
\text { molecular weight heparin }\end{array}$ \\
\hline Main field of application & $\begin{array}{l}\text { preoperative screening in cases } \\
\text { of positive bleeding history ('in } \\
\text { vitro BT'); von Willebrand } \\
\text { syndrome; control of success for } \\
\text { ASA or DDAVP therapy }\end{array}$ & $\begin{array}{l}\text { perioperative POC platelet function } \\
\text { analysis; control of success for ASA, } \\
\text { DDAVP, clopidogrel or GPIIb/IIIa } \\
\text { receptor inhibitor therapy }\end{array}$ & $\begin{array}{l}\text { perioperative POC coagulation } \\
\text { management; whole blood coagulation } \\
\text { test with special consideration of clot } \\
\text { firmness and stability }\end{array}$ \\
\hline
\end{tabular}

ASA = acetylsalicylic acid; AU = aggregation units; DDAVP = desamino-delta-D-arginine vasopressin (desmopressin); PAR = protease-activated receptor; $\mathrm{POC}=$ point-of-care; TRAP = thrombin receptor activating peptide; TEM = thrombelastometry; NATEM = native TEM; ExTEM extrinsic activated TEM; InTEM = intrinsic activated TEM; FibTEM = fibrin clot TEM; ApTEM = aprotinin TEM; HepTEM = heparinase TEM;

EcaTEM = ecarin TEM; X-TEM = TEM with several coagulation factors as an additive (not commercially available). 
- von Willebrand syndrome,

- acetylsalicylic acid (ASA),

- clopidogrel,

- GPIIb/IIIa receptor inhibitors (abciximab, eptifibatide, tirofiban),

- non-specific platelet function disturbances (e.g. in connection with uraemia, liver cirrhosis, cardiopulmonary bypass, ECMO therapy).

- Which function (receptor) shall be monitored?

- platelet adhesion (GPIb/V/IX receptor; von Willebrand factor),

- stimulation with epinephrine ( $\alpha_{2 \mathrm{~A}}$ receptor),

- stimulation with collagen (GPIa/IIa receptor),

- stimulation with arachidonic acid (AA) (activity of cyclooxygenase (COX) 1),

- stimulation with ADP (P2Y12 ADP receptor),

- stimulation with thrombin (PAR1 and PAR4 receptor),

- platelet aggregation (activation of the GPIIb/IIIa receptor),

- platelet aggregation (inhibition of the GPIIb/IIIa receptor),

- clot firmness and stability (fibrinogen-platelet interaction).

- Which kind of treatment shall be monitored?

- DDAVP (desmopressin),

- antifibrinolytics (e.g. aprotinin or tranexamic acid),

- fibrinogen concentrate (or cryoprecipitate),

- coagulation factor concentrates (e.g. prothrombin complex concentrate $(\mathrm{PCC}=\mathrm{PPSB}))$ or FFP,

- PC.

- Under which flow condition shall be tested?

- dynamic (with high shear stress blood flow),

- static (without high shear stress blood flow).

\section{Standardized Questionnaire for Bleeding History}

One main problem - not only in platelet function analysis - is to ask the right questions. Preoperative coagulation screening should answer the question 'Will this patient bleed?'. Actual studies could demonstrate that tests, which were currently used for preoperative screening for coagulation disorders like prothrombin time (PT), activated partial thromboplastin time (aPTT) and platelet count -, do often not adequately predict intra- or postoperative bleeding complications [36-40]. For example the aPTT was developed to assist the diagnostic use for patients with signs of haemophilia and the question was 'Why does this patient bleed?'. As the aPTT was never intended to answer the question 'Will this patient bleed?', one has to be careful regarding interpretation of aPTT results in this direction. Prolonged aPTT is neither strongly predictive for haemorrhage, nor does a normal aPTT rules out haemorrhagic complications [41]. The main reason for this lack of sensitivity is that aPTT and PT focus on detection of plasmatic coagulation disorders - like haemophilia (incidence 1:10,000) or deficiency of vitamin K-dependent coagulation factors whereas hereditary (e.g. von Willebrand syndrome; incidence $1: 1,000)$ or acquired impairment of primary haemostasis (acquired von Willebrand syndrome in patients with hypothyroidism or aortic stenosis; platelet function disorders in patients with antiplatelet or herbal medicine therapy) are the most frequent causes of unexpected bleeding in the perioperative phase [42-49]. Besides, factor XIII deficiency may play a major role in some cases of perioperative bleeding problems, which also often shows no correlation to routinely determined preoperative coagulation tests [47, 50-52]. Among all conventional coagulation tests, only the decrease of fibrinogen was an early predictor of the severity of postpartum haemorrhage in a multicentre study in France [53].

Koscielny et al. $[54,55]$ has shown in a large prospective study with 5,649 unselected adult patients that the use of a standardized questionnaire and - if indicated - platelet function analysis with PFA-100 is superior to commonly used coagulation tests (aPTT, PT and platelet count) in detection of impaired haemostasis before surgical interventions and also allows a significant reduction of laboratory costs. In addition, preoperative correction of impaired haemostasis results in a reduction of bleeding complications and homologous blood transfusions [56]. On the other hand, the study of Roschitz et al. [57] shows that the PFA-100 is probably only a good screening method when a haemostatic defect in a patient is clinically likely, especially to screen for von Willebrand syndrome, and the test should not be used in general unselective screening without positive bleeding history. Based on the above mentioned studies and consensus of experts, the scientific committee of the Deutsche Gesellschaft für Anästhesie und Intensivmedizin (DGAI) in agreement with the Deutsche Gesellschaft für Hals-Nasen-Ohren-Heilkunde, Kopf- und Hals-Chirurgie (DGHNOKC) and the Gesellschaft für Thrombose- und Hämostaseforschung (GTH), as well as with the subcommittee for perioperative coagulation of the Österreichische Gesellschaft für Anaesthesiologie, Reanimation und Intensivmedizin (ÖGARI) recommend the use of a standardized questionnaire to detect an increased risk of bleeding [58, 59]. Accordingly, healthy patients of the ASA grades I and II without any suspicion of impaired haemostasis who are scheduled for procedures without expected transfusion requirements, need no standard tests for coagulation. In all other patients - including patients taking medication affecting coagulation, or patients who are unable to provide adequate information - platelet count, platelet function (i.e. with PFA-100), aPTT, PT, and fibrinogen levels should be assessed. In cases of positive history of coagulation disorders sophisticated diagnostic tests should be initiated after consulting a specialist in haemostasis. Since there are several modifications of standardized questionnnaire for preexisting coagulation disorders in use, DGAI authorized the scientific committees for regional anaesthesia and paediatric anaesthesia to develop a common standardized questionnaire. 
The decision to discontinue an antiplatelet therapy with ASA and clopidogrel - especially in patients with coronary artery (drug-eluting!) stents - has to be based on an interdisciplinary risk-benefit estimation [60-69]. Platelet function analysis with PFA-100 or Multiplate may be helpful in estimating the risk of bleeding in this population.

\section{Platelet Function Analyzer 100 (PFA-100)}

\section{Blood Samples and Measuring Method}

PFA-100 is a platelet function analyzer designed to examine platelet-related primary haemostasis. PFA-100 uses whole citrated blood and high shear stress blood flow to simulate primary haemostasis. The analysis has to be proceeded within $0.5-2 \mathrm{~h}$ after sampling. A small volume of blood is introduced into a disposable cartridge and forced through a capillary tube. Platelet adhesion and aggregation is then initiated following exposure to either collagen/epinephrine(PFA-EPI)- or collagen/adenosine-diphosphate(PFA-ADP)-coated membranes. The time needed for occluding the apperture in the collagen membrane by plug formation yields the measured endpoint called closure time (CT in s) [70-72].

\section{Measurement and Reference Range}

The measurement range is $40-300 \mathrm{~s}$. The reference range for PFA-EPI is about 80-160 s and for PFA-ADP 60-120 s [70, 71, 73]. Duplicate analyses reveal mean coefficient of variations of $7.1 \%$ for PFA-EPI and $5.7 \%$ for PFA-ADP [72, 74]. The $\mathrm{CT}$ is longer in blood group $\mathrm{O}$ patients than in patients with other blood groups, and the CTs of blood samples collected in the evening are significantly longer than CTs of blood samples collected in the morning [72, 74].

\section{Indications}

PFA-100 is highly sensitive to the presence of von Willebrand syndrome. These patients give prolonged CTs using PFA-EPI (CT $\geq 200 \mathrm{~s}$ ), whereas PFA-ADP is less sensitive. Haemophilia or fibrinogen deficiency do not influence CT. Thrombocytopenia offer normal or prolonged CTs, dependent on platelet count. Administration of ASA results in a prolongation of PFA-EPI, whereas PFA-ADP is not affected. PFA-EPI is more sensitive in detecting ASA ingestion than the bleeding time (BT). Furthermore, administration of desamino-delta-Darginine vasopressin (DDAVP) in patients with von Willebrand syndrome or ASA intake results in a shortening of CT in PFA-EPI. Therefore, PFA-100 can be used as a marker for DDAVP responsiveness and monitoring of DDAVP therapy $[55,56,73,75]$.

\section{Limitations}

Thrombocytopenia with a platelet count below 100/nl and anaemia with a haematocrit below $35 \%$ resulted in a prolongation of CT. On the other hand, platelet activation during surgery can cause the generation of platelet aggregates, which may lead to a shortening of CT. Therefore, PFA-100 results are not easy to interpret during surgery. The predictive value of PFA-100 for postoperative blood loss in routine cardiac surgery is low, but postoperative shortening of CT values may be helpful to identify patients with hyperreactivity of platelets associated with the risk of myocardial lesion and ischaemia [74, 76-78].

Whereas ASA resistance detected by Born aggregometry (incidence $5.5 \%$ ) in a study conducted by Gum et al. [79] resulted in a three-fold increase in major adverse events (death, myocardial infarction, or cerebrovascular accident) within 2 years of ASA therapy in cardiovascular patients, in the same study population ASA resistance detected by PFA-100 (incidence $9.5 \%$ ) was not associated with an increase in major adverse events [80]. This difference in terms of the incidence of in vitro ASA resistance detected by Born aggregometry and PFA-100 may be explained by the finding of Chakroun et al. [81] that ASA resistance in PFA-100 (PFA-EPI: CT $<200$ s) is associated with increased plasma concentrations of von Willebrand factor in these patients.

Because of the very high sensitivity to effects of GPIIb/IIIa receptor inhibitors - like abciximab, eptifibatide, or tirofiban -, the CT of PFA-100 passes the measurement range already at low dosage. In contrast, whole blood impedance aggregometry (Multiplate) shows a dose-dependent correlation between AUC (area under the curve) values and blood concentration of GPIIb/IIIa receptor inhibitors within the whole therapeutic range [82].

Whereas PFA-100 is very sensitive for von Willebrand syndrome and ASA effects, clopidogrel effects cannot be definitely detected [83-85]. This limitation has to be considered in context with the increasing number of patients with a combined ASA/clopidogrel therapy after coronary stent implantation $[61,62,65,66]$. Several studies demonstrated an association between preoperative use of clopidogrel in combination with ASA and increased risk of bleeding, increased transfusion requirements and need for surgical re-exploration [60, 64, $68,69]$. In this regard too, whole blood impedance aggregometry (Multiplate) is superior to PFA-100 [86-89].

\section{Conclusions}

PFA-100 is a useful tool for preoperative screening of patients for platelet-related haemostatic defects. PFA-100 ('in vitro BT') is sensitive to ASA intake and other abnormalities of primary haemostasis, like von Willebrand syndrome, Bernard-Soulier syndrome, storage pool disease or Glanzmann's thrombasthenia. Its use is preferable to BT determination because it is less invasive and more sensitive to abnormalities of primary haemostasis [72]. Since a prolonged CT not always is associated with clinically relevant bleeding disorders, PFA-100 is probably only a good screening method when a haemostatic defect in a patient is clinically likely, particularly in patients with positive bleeding history, hypothreoidism or aortic stenosis [42, 49, 90]. 
Therefore, the test should not be used in general unselective screening without positive bleeding history [54, 57, 58, 91, 92]. Furthermore, the limitations in drug monitoring for clopidogrel and GPIIb/IIIa receptor inhibitors have to be kept in mind.

\section{Multiple Platelet Function Analyzer (Multiplate)}

\section{Blood Samples and Measuring Method}

The Multiplate analyzer is a new platelet function analyzer based on whole blood impedance aggregometry. Impedance aggregometry was developed by Cardinal and Flower and has been used since the 1980s for the assessment of platelet function in whole blood. Impedance aggregometry is based on the principle that blood platelets are non-thrombogenic in their resting state, but expose receptors on their surface when they get activated, which allow them to attach on vascular injuries and artificial surfaces. Multiplate analysis takes place in a single use test cell which incorporates a dual sensor unit and a PTFE-coated stirring magnet. The sensor wires are silver-coated. When platelets stick on the Multiplate sensor wires, they enhance the electrical resistance between them, which is continuously recorded. In order to enhance resistance on the sensor wires a tight attachment of platelets is required. Increase in impedance is expressed in arbitrary 'Aggregation Units' (AU). Three parameters are calculated after Multiplate analysis: aggregation (in $\mathrm{AU}$ ), velocity (in $\mathrm{AU} / \mathrm{min}), \mathrm{AUC}$ in $(\mathrm{AU} \times$ min). Thereby, AUC highlighted as the parameter with the highest diagnostic power [93, 94].

The fact that aggregation in Multiplate takes place on surfaces is a major difference compared to other methods such as Born aggregometry and single platelet counting. In Born aggregometry and single platelet counting methods, platelets aggregate with each other in the liquid phase. This presumably happens only in severely ill patients - e.g. during heparin-induced thrombocytopenia type II or disseminated intravascular coagulation - as coagulation and platelet aggregation in vivo usually only take place on surfaces.

Multiplate uses anticoagulated whole blood for analysis. Whole blood is the physiological environment where platelet function takes place in vivo, and the use of whole blood for in vitro testing eliminates the need for time-consuming centrifugation steps required for Born aggregation measurements. By using citrated blood, platelet function is inhibited probably by a decrease in intracellular calcium concentration in platelets. Therefore, better results can be obtained by performing anticoagulation with heparin or hirudin [95-97]. The Multiplate results are most reproducible by using hirudin as an anticoagulant [95]. Under special conditions - like cardiac surgery where the patient is already under complete anticoagulation with heparin, in our experience it is not necessary to add an additional anticoagulant to the blood sample.

The analysis should be proceeded within 0.5-2 h after sampling [95]. The analysis itself needs $3 \mathrm{~min}$ for incubation and 6 min for the measurement after stimulation. Several specific test reagents are available for stimulation of different receptors or activation of signal transduction pathways of platelets in order to detect changes induced by drugs as well as by acquired or hereditary platelet disorders. The following tests can be used:

- ASPItest: AA is the substrate for COX. COX forms thromboxane $\mathrm{A}_{2}\left(\mathrm{TXA}_{2}\right)$, which is a potent platelet agonist. COX is inactivated irreversibly by ASA and reversibly by several antiinflammatory drugs.

- COLtest: Collagen activates the collagen receptor (GPIa/IIa receptor), which leads to a release of endogenous AA. AA in turn is converted to $\mathrm{TXA}_{2}$ and thereby results in a further activation of platelets.

- ADPtest: ADP activates platelet by stimulation of ADP receptors. The most important ADP receptor $\left(\mathrm{P}_{2} \mathrm{Y}_{12}\right)$ is blocked by clopidogrel, prasugrel and ticlopidine.

- ADPtest HS: Compared to ADPtest, the addition of the endogenous platelet inhibitor $\mathrm{PGE}_{1}$ makes ADPtest HS more sensitive towards the effects of clopidogrel and related drugs.

- TRAPtest: TRAP-6 stimulates the thrombin receptors PAR1 and PAR4 on the platelet surface. Thrombin is the most potent platelet activator. Its action is not blocked by ASA or clopidogrel. TRAPtest allows to detect the effect of GPIIb/IIIa receptor inhibitors also in blood samples from patients treated with ASA or clopidogrel.

- RISTOtest high and low: These tests are based on ristocetin-induced platelet aggregation. The concentrations are chosen so that typically a sample will not or only weakly aggregate in RISTOtest low and will aggregate well in RISTOtest high. This allows the detection of samples with enhanced tendency of ristocetin-induced aggregation, particularly in von Willebrand syndrome type IIb. On the other hand, blood samples from patients with BernardSoulier syndrome, von Willebrand syndrome type III and severe von Willebrand syndrome type I and II are characterized by an absent or markedly reduced response to ristocetin [98].

\section{Measurement and Reference Range}

The reference range is dependent on the anticoagulant applied in the blood sample and the reagent used for stimulation in the Multiplate analysis (table 2). In contrast to PFA-100, no significant differences between blood group $\mathrm{O}$ and non- $\mathrm{O}$ individuals can be noted, and Multiplate values do not change significantly during the day [99].

\section{Indications}

Multiplate shows a high sensitivity towards the effects of platelet inhibitors such as ASA, clopidogrel and GPIIb/IIIa receptor inhibitors (abciximab, eptifibatide and tirofiban) and also towards the newer direct ADP receptor antagonists [86, $88,89,98,100,101]$. In contrast to PFA-100, Multiplate shows 


\begin{tabular}{|c|c|c|c|c|c|}
\hline & \multicolumn{5}{|c|}{ Multiplate tests } \\
\hline & ASPItest & COLtest & ADPtest & ADPtest HS & TRAPtest \\
\hline Activator & AA & collagen & ADP & $\mathrm{ADP}+\mathrm{PGE} 1$ & TRAP-6 \\
\hline Final concentration & $0.5 \mathrm{mmol} / \mathrm{l}$ & $3.2 \mu \mathrm{g} / \mathrm{ml}$ & $6.4 \mu \mathrm{mol} / 1$ & $6.4 \mu \mathrm{mol} / 1$ & $32 \mu \mathrm{mol} / 1$ \\
\hline Reference range (healthy blood donors), $\mathrm{AU} \times \min [98]$ & $740-1,360$ & $460-1,160$ & $530-1,220$ & $310-1,070$ & $940-1,560$ \\
\hline Target range for antiplatelet therapy ${ }^{\mathrm{a}}, \mathrm{AU} \times \min [98]$ & $<300$ & $<550$ & $<500$ & $<250$ & $<300$ \\
\hline \multicolumn{6}{|l|}{ Cut-off for platelet transfusion in bleeding patients, } \\
\hline $\mathrm{AU} \times \min [96,106,121]$ & $<200$ & $<200$ & $<300$ & - & $<500$ \\
\hline
\end{tabular}

${ }^{a}$ Antiplatelet therapy with ASA, clopidogrel, and tirofiban.

Table 3. ROTEM reference values $[110,113]$

\begin{tabular}{lllllll}
\hline ROTEM parameter & CT, s & CFT, s & A10, mm & A20, mm & MCF, mm & CLI $60, \%$ \\
\hline ExTEM & $40-80$ & $34-160$ & $44-66$ & $50-71$ & $50-72$ & $85-100$ \\
InTEM & $100-240$ & $30-110$ & $44-66$ & $50-71$ & $50-72$ & $85-100$ \\
HepTEM $^{\text {a }}$ & $100-240$ & $30-110$ & & & $50-72$ & $85-100$ \\
FibTEM $^{\text {b }}$ & - & - & $7-23$ & $8-24$ & $8-24$ & - \\
ApTEM $^{c}$ & $40-80$ & $34-160$ & $44-66$ & $50-71$ & $50-72$ & - \\
\hline
\end{tabular}

a Distinct shortening of CT in HepTEM compared to InTEM indicates a heparin effect.

${ }^{\mathrm{b}} \mathrm{MCF}_{\mathrm{FIB}}<8 \mathrm{~mm} \rightarrow$ fibrinogen deficiency $(<1 \mathrm{~g} / \mathrm{l})$ or fibrinogen polymerisation disorder. MCF $\mathrm{FIIB}$ $>24 \mathrm{~mm} \rightarrow$ elevated fibrinogen concentration $(\geq 3 \mathrm{~g} / 1)$. This can result in normal $\mathrm{MCF}_{\mathrm{Ex}}$ even in thrombocytopenic patients.

'Shortening of CT or increase in MCF in ApTEM compared to ExTEM can be a sign of hyperfibrinolysis.

a dose-dependent correlation between AUC values and blood concentration of GPIIb/IIIa receptor inhibitors within the whole therapeutic range [82]. Multiplate can also be used for monitoring of the reversing effect of DDAVP on COX 1-induced platelet inhibition [102].

Whereas up to now a simple and reliable method for ex vivo examination of platelet function in PC was not available, the Multiplate analyzer seems to be a helpful tool for this indication [27, 103]. Furthermore, Rahe-Meyer et al. [96, 97] could demonstrate the predictive value of Multiplate analysis regarding transfusion requirements during and after cardiac surgery. Moreover, the study of Poston et al. [104] provides evidence that thrombelastography and whole blood aggregometry is predictive for both bleeding complications and thrombosis after off-pump coronary artery bypass surgery. Therefore, Poston et al. [104] postulate that titration of perioperative platelet function, according to thrombelastography and whole blood aggregometry results, may minimize the risk of thrombosis without increase in bleeding complications.

\section{Limitations}

There are only few data concerning the sensitivity of the Multiplate analyzer to von Willebrand syndrome [105]. Furthermore, it has to be kept in mind, that determination of von Willebrand factor in RISTOtest takes place under low shear stress conditions and the artificial addition of ristocetin. Moreover, other methods - like PFA-100 - are more specific and sensitive for diagnosis of von Willebrand syndrome type I and type II [98].

Results of Multiplate analysis correlate significantly with platelet count and reflect interactions between platelets, erythrocytes and leucocytes. This explains differences between the results of whole blood impedance aggregometry (Multiplate) and platelet function analyzers using platelet-rich plasma [99]. Since the Multiplate analyzer is a very new device, only limited data exist about its diagnostic power. Therefore, the clinical significance of whole blood impedance aggregometry using the Multiplate system remains to be determined in further studies on patients with abnormalities of primary haemostasis.

\section{Conclusions}

In addition to the high sensitivity towards the effects of platelet inhibitors (including ASA, clopidogrel, and GPIIb/ IIIa receptor inhibitors), the Multiplate analyzer - especially in combination with thrombelastometry (ROTEM) - is predictive for both bleeding complications and thrombosis. This may allow titration of perioperative platelet function to minimize the risk of bleeding and thrombosis. Therefore, the combined use of these two tools may be optimal for POC coagulation management during cardiac surgery $[7,106]$. 


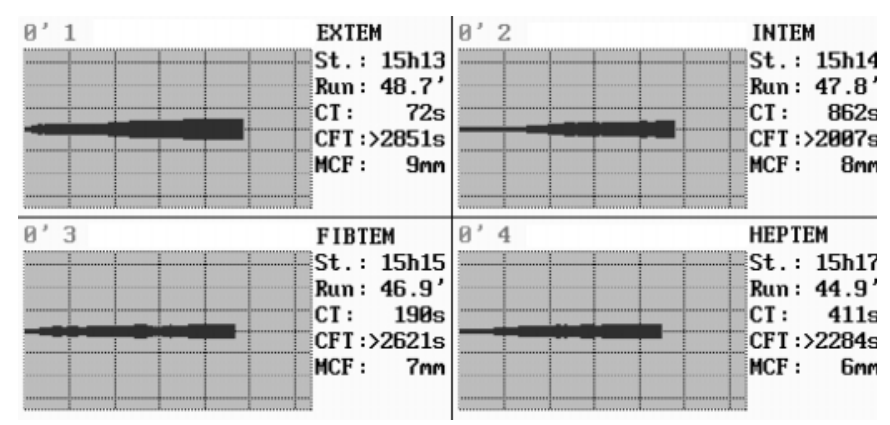

Fig. 1. ROTEM analysis in a patient with petechia and mucosal bleeding without thrombocytopenia (platelet count 260/nl): $\mathrm{MCF}_{\mathrm{EX}}=9 \mathrm{~mm}$ and $\mathrm{MCF}_{\text {FIB }}=7 \mathrm{~mm}$. Conventional laboratory tests: fibrinogen $1.9 \mathrm{~g} / \mathrm{l}$; Quick (PT in \%) 72\%; aPTT $32.7 \mathrm{~s}$; TT >60 s; antithrombin 115\%; D-dimers > $6,400 \mu \mathrm{g} / \mathrm{l}$.

\section{Rotational Thrombelastometry (ROTEM)}

\section{Blood Samples and Measuring Method}

ROTEM analysis uses $300 \mu \mathrm{l}$ of citrated whole blood for each measurement. It allows the evaluation of the coagulation system as an holistic dynamic process. The principle of rotational thromboelastometry (ROTEM) is related to, but in some aspects different from, classical thromboelastography, which was first described by Hartert in 1948 [107, 108]. In contrast to classical thrombelastography (TEG ${ }^{\circledR}$, Haemoscope, Niles, IL, USA) the cup is fixed in a temperature-controlled cup holder, and the pin rotates back and forth through an angle of $4.75^{\circ}$ with a cycle time $10 / \mathrm{min}$. The movement of the pin is driven by an elastic spring and is guided by a high precision ball bearing system. The exact position of the pin axis is detected by the reflection of light by a small mirror which is attached to the shaft. The loss of the elasticity upon clotting of the sample leads to a change in rotation of the pin. This is detected by a CCD array, and the data are automatically analysed by computer $[109,110]$. The stabilisation of the pin by a ball bearing system and the opto-mechanical detection method provides a good protection against the impact of vibrations and mechanical shocks. This allows the usage of the ROTEM system as a mobile unit, which can be transported easily to the operation theatre for POC coagulation management.

The ROTEM ${ }^{\circledR}$ system comes with four independent channels which enable the performance of four independent tests at the same time. The use of an automatic electronic pipette and computer-assisted operation procedures and analysis of the data make the ROTEM system easy to use.

ROTEM tests are started by re-calcification and accelerated by adding an activator of the extrinsic or intrinsic coagulation pathway. Thromboplastin (tissue factor) from rabbit brain is used for activation of the extrinsic pathway in ExTEM, FibTEM and ApTEM (for explanation of abbreviations see footnote of table 1). FibTEM contains additional cytochalasin

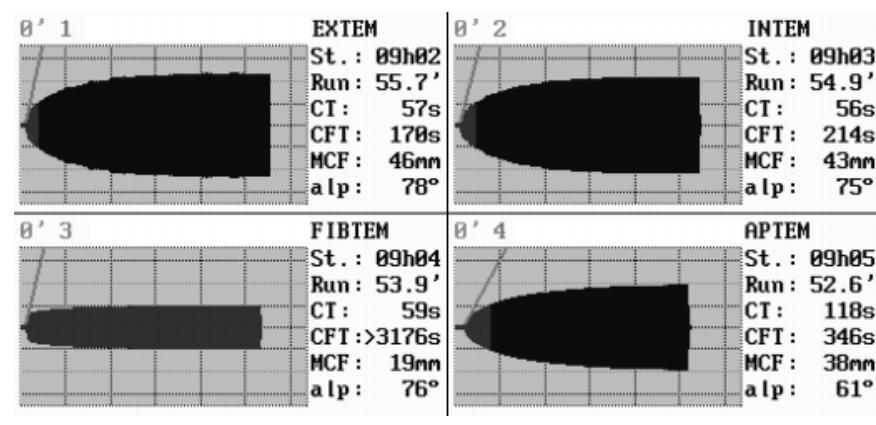

Fig. 2. ROTEM analysis in a patient with severe thrombocytopenia (platelet count 22/nl) without spontaneous bleeding: $\mathrm{MCF}_{\mathrm{EX}}=46 \mathrm{~mm}$ and $\mathrm{MCF}_{\mathrm{FIB}}=19 \mathrm{~mm}$. Conventional laboratory tests: fibrinogen $4.2 \mathrm{~g} / \mathrm{l}$; Quick (PT in \%) $76 \%$; aPTT 29.8 s; antithrombin $48 \%$.

$\mathrm{D}$ in order to inhibit platelet activation $[111,112]$. ApTEM includes aprotinin in order to block hyperfibrinolysis. All extrinsic activated tests include an heparin inhibitor which is able to eliminate the effect of up to $6 \mathrm{IU}$ heparin per ml blood. In InTEM (intrinsic pathway clotting time) test coagulation is activated by partial thromboplastin (phospholipids) and ellagic acid. HepTEM is an InTEM test with additional heparinase in order to eliminate the heparin effect [110].

\section{ROTEM Parameters and Reference Range}

Unlike conventional clotting assays, ROTEM determines not only the clotting time (in s), but also the dynamics of clot formation $(\mathrm{CFT}=$ clot formation time in $\mathrm{s})$, the mechanical clot stability (A5, A10, A15 = amplitude at 5, 10 or $15 \mathrm{~min}$ in $\mathrm{mm}$; $\mathrm{MCF}=$ maximum clot firmness in $\mathrm{mm}$ ) and its lysis over the time $(\mathrm{ML}=$ maximum lysis in $\%=$ reduction of clot firmness in relation to $\mathrm{MCF}$ within the complete measurement period; CLI30, CLI45, CLI60 = clot lysis index at 30, 45 or $60 \mathrm{~min}$ in \% $=$ remaining clot firmness at fixed test timepoints in relation to MCF) [110]. By using activated tests ROTEM results can be interpreted after 10-15 min. Clot firmness achieves its maximum normally after 20-30 min. To detect a late hyperfibrinolysis, ROTEM tests have to be monitored for up to $60 \mathrm{~min}$ [22]. For reference values see table 3 .

\section{Indications}

ROTEM analysis allows reliable detection of hyperfibrinolysis, fibrinogen deficiency and fibrinogen polymerisation disorders, thrombocytopenia and platelet function disorders, coagulation factor deficiencies and heparin effects [114-116] (fig. 1, 2). Clot firmness (A10 or MCF) in ExTEM and FibTEM have to be compared to differentiate between fibrinogen deficiency/polymerisation disorders and thrombocytopenia/platelet function disorders [111, 110, 117]. Heparin effects as well as a protamine overdosage can be detected or excluded by comparing the clotting times of InTEM and 
Fig. 3. Algorithm for ROTEM- and Multiplate-based POC coagulation management in cardiac surgery; part 1 - management before weaning from cardiopulmonary bypass $[106,121]$.

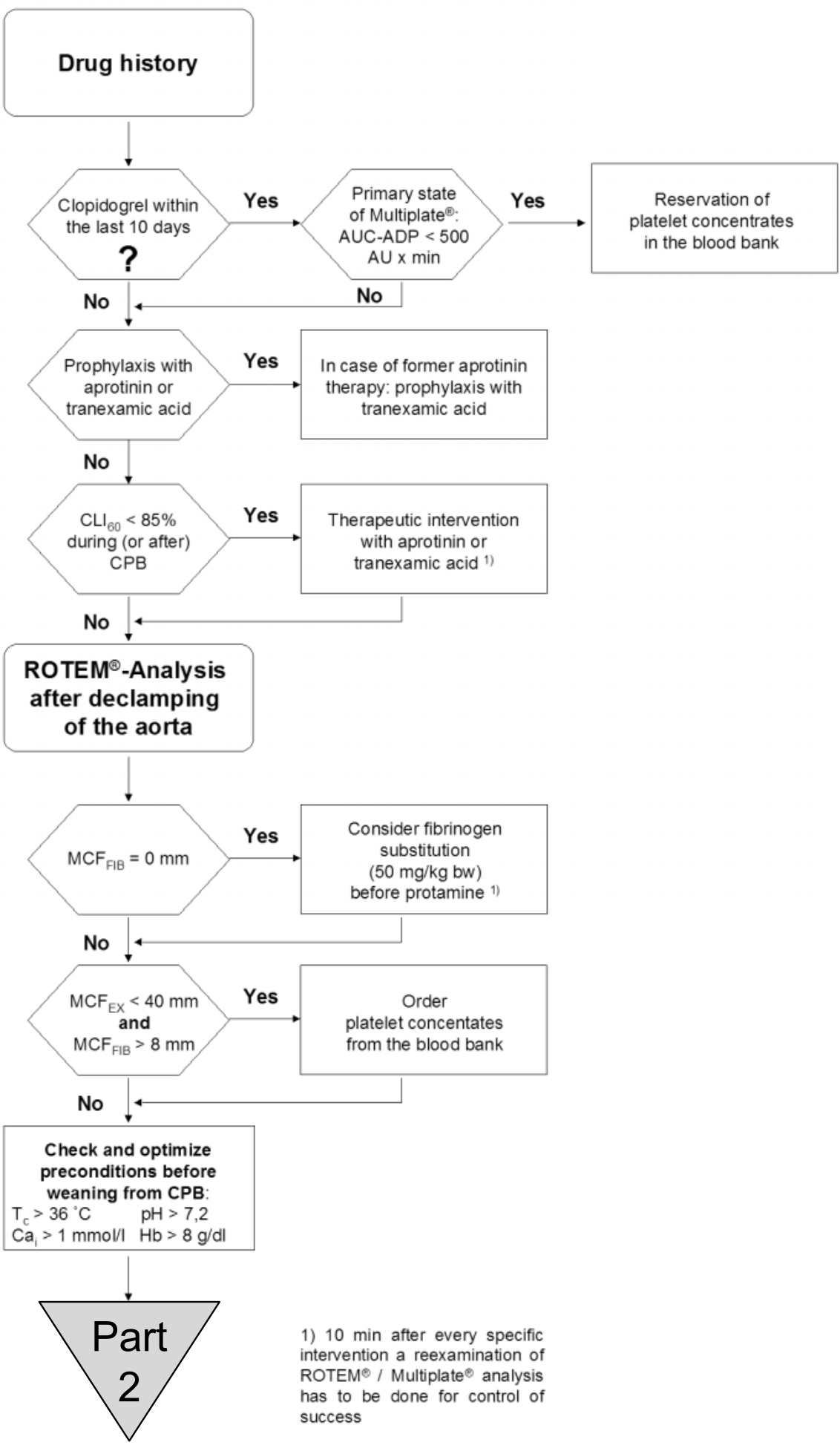

HepTEM [22, 116, 118]. Cho et al. [119] demonstrated in their study that residual heparin effects can be detected more sensitively by TEG/heparinase-TEG than by activated clotting time (ACT) / heparinase-ACT. Furthermore, the use of heparinase enables monitoring of haemostasis even in completely heparinised patients during cardiopulmonary bypass $[78,110,118,120,121]$. As the ROTEM system allows mea- surement at a large temperature range $\left(30-40^{\circ} \mathrm{C}\right)$, the effects of hypo- and hyperthermia on the coagulation system can be verified [22, 122]. Finally, diagnostic or therapeutic additives (e.g. aprotinin, heparinase, ecarin, recombinant factor VIIa, factor VIII or factor XIII) can be used for in vitro testing in order to predict the efficiency of a risky or expensive therapy in vivo [22]. 
Fig. 4. Algorithm for ROTEM- and Multiplate-based POC coagulation management in cardiac surgery; part 2 - management after weaning from cardiopulmonary bypass $[106$, 121].

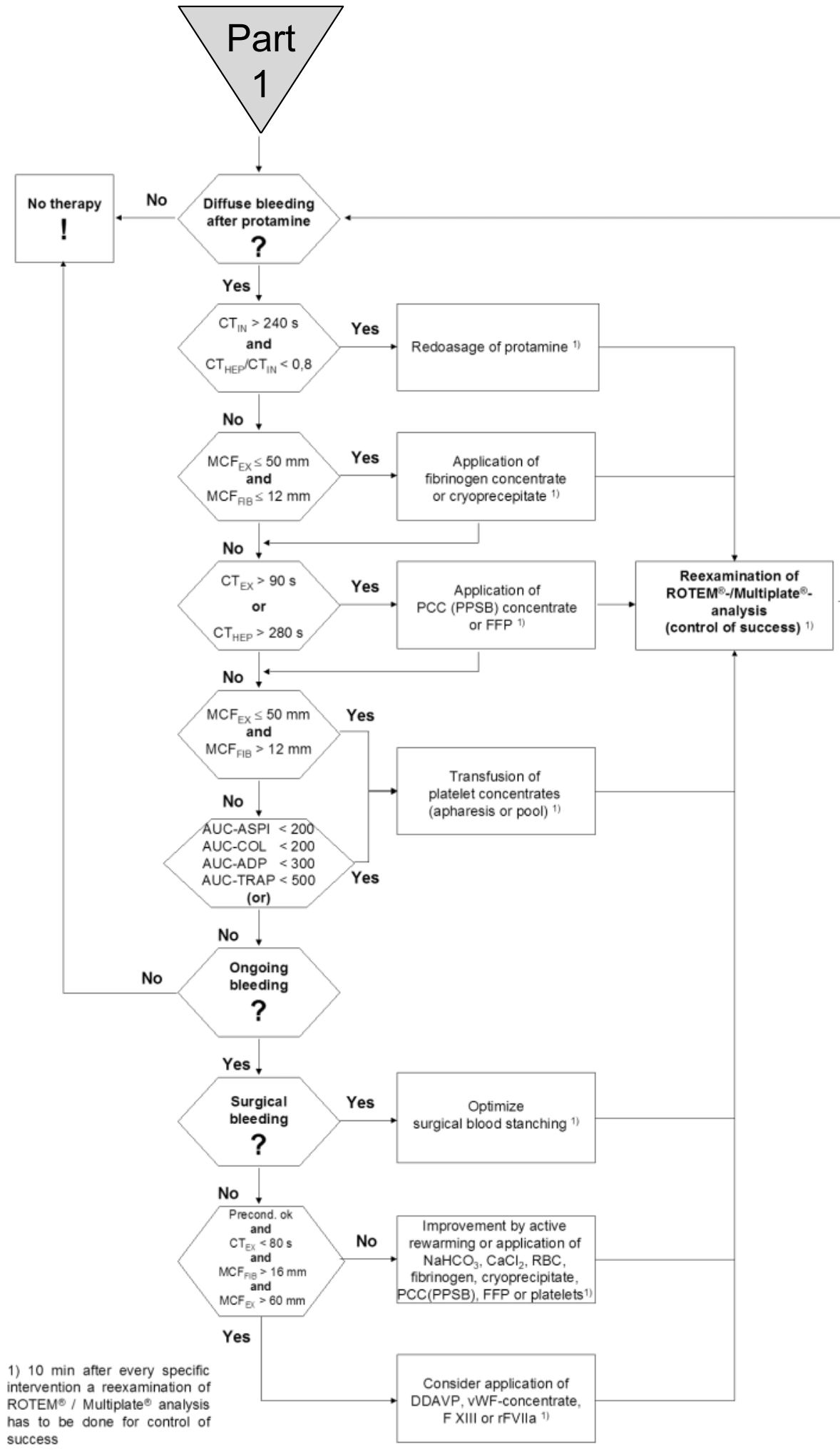

- The effects of antiplatelet drugs - like ASA or ADP antagonists (clopidogrel, ticlopidine) - cannot be detected because activation of platelets by thrombin overrules the effects of platelet aggregation inhibitors.

- GPIIb/IIIa receptor antagonists in normal therapeutic 

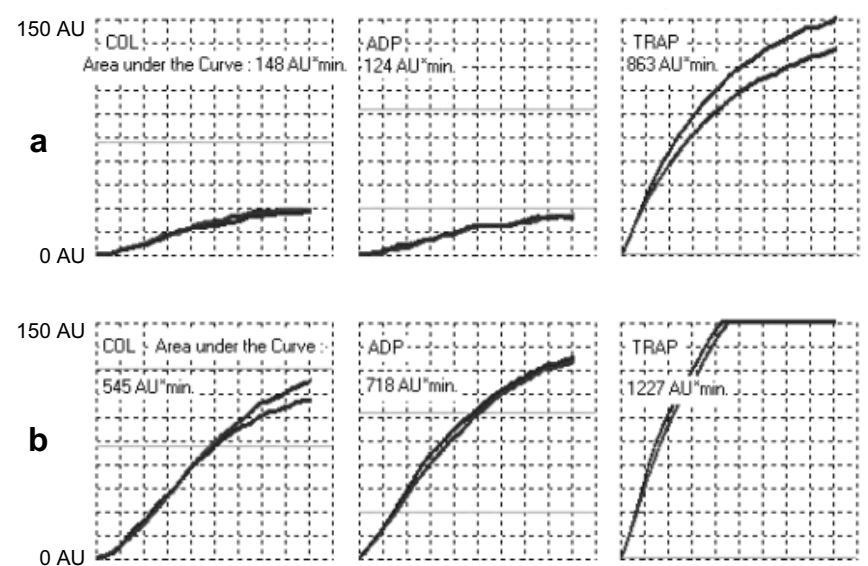

Fig. 5. a Multiplate analysis in a ASA and clopidogrel responder (AUC$\left.\mathrm{COL}<300 \mathrm{AU} \times \min ; \mathrm{AUC}_{\mathrm{ADP}}<500 \mathrm{AU} \times \mathrm{min}\right)$. b Multiplate analysis in a ASA and clopidogrel 'nonresponder' $(\mathrm{AUC} C \mathrm{COL}>300 \mathrm{AU} \times$ min; $\mathrm{AU}-$ $\left.\mathrm{C}_{\mathrm{ADP}}>500 \mathrm{AU} \times \min \right)$.

dosage or mild Glanzmann's disease do not necessarily reduce MCF measured in ROTEM.

- There is a minor correlation between CT in ExTEM and PT. Therefore, determination of PT in addition to ROTEM tests can be helpful for calculation of the therapeutic dose of PCC.

\section{Conclusions}

Compared to PFA-100 and conventional coagulation tests, including ACT, TEG/ROTEM is superior in predicting blood loss during and after cardiac surgery $[76,124]$. The best predictors of increased bleeding tendency in ROTEM analysis are the CFT or the MCF in HepTEM and the MCF in FibTEM $[76,125,126]$. Recent studies have shown that, compared to conventional coagulation management, TEG/ ROTEM-based POC coagulation management enables reduction of transfusion requirements and costs in cardiac and liver surgery [7, 30, 33, 34, 127, 128]. Furthermore, TEG/ROTEM may be helpful to identify patients with elevated risk of postoperative thrombotic complications including myocardial infarction $[78,129]$.

However, it must be considered that impaired primary haemostasis because of von Willebrand syndrome or the effect of antiplatelet drugs - like ASA or clopidogrel - cannot be detected by ROTEM analysis. Therefore, in cases in which primary haemostasis may be affected - especially in cardiac surgery - a combined use of ROTEM and platelet function analysis (PFA-100 or Multiplate) should be preferred for POC coagulation management $[106,121]$.

\section{POC Coagulation Management in Cardiac Surgery}

After implementation of a ROTEM-based POC coagulation management in the field of visceral and transplantation surgery in 2000, the overall intraoperative use of blood components could be reduced by 56\% until 2006 (PRBC by 30\%, FFP by $73 \%$, and PC by $69 \%$ ) [7]. A reduction of perioperative blood loss and transfusion requirements in cardiosurgical patients by the use of POC tests could also be demonstrated by other authors [30-34, 130]. Based on our experience in ROTEM-based POC coagulation management in liver transplantation and multiple trauma patients we started with ROTEM diagnostics in thoracic and cardiovascular surgery in April 2004 and with Multiplate analysis in December 2005.

\section{Treatment of Platelet Function Disorders in Cardiac Surgery}

Many patients in cardiac surgery are pretreated with antiplatelet drugs. Furthermore, extracorporeal circulation is responsible for multifactorial platelet function disorders. The platelets are damaged mechanically by the pump and are activated by contact with the artificial surface of the cardiopulmonary bypass circuit. Hypothermia also induces platelet function disorders [24, 122, 131, 132]. In addition, heparin can cause an unspecific activation and therefore a consumption of platelets [133]. Routinely POC platelet function analysis is so far not established everywhere. Impedance aggregometry with the Multiplate analyzer may close this gap in the future, but more evaluation studies are necessary [96]. The critical value for platelet substitution in cardiac surgery given by the Bundesärztekammer is $100 / n l$. In case of bleeding, the administration of platelets should be considered independently from platelet count if there is any suspicion for severe platelet function disorders (e.g. in context with clopidogrel pretreatment or cardiopulmonary bypass time of more than $3 \mathrm{~h}$ ). Furthermore, a haemoglobin level of $8-10 \mathrm{mg} / \mathrm{dl}$ or a haematocrit of $24-30 \%$ is needed to marginate platelets to the vessel wall and to enable an interaction with subendothelial collagen in the area of vascular lesions [134, 135]. ROTEM and Multiplate analysis allow an evaluation of platelet function independent of the number of platelets [96].

\section{Algorithm for POC Coagulation Management in Cardiac Surgery}

As it has been demonstrated by other authors [6, 31-33, 130, 136, 137], experience-based diagnostic and therapeutic algorithms are able to reduce perioperative blood loss and transfusion requirements in cardiac surgery. This could already be proven for POC coagulation management during liver transplantation in our clinic in Essen [7]. Based on our experience with POC coagulation management, we developed - in cooperation with our colleagues from the university clinics of Frankfurt/M. and Hannover - an algorithm for ROTEM and Multiplate based coagulation management in cardiac surgery which was first presented at the Deutscher Anästhesie-Con- 
Fig. 6. a Multiplate analysis at the beginning of cardiopulmonary bypass $-4 \mathrm{~h}$ after termination of eptifibatide infusion (co-medication with ASA and clopidogrel) in a patient with acute coronary syndrome: diffuse bleeding after the fist cut. b Multiplate analysis in the same patients after weaning from cardiopulmonary bypass and heparin reversal with protamine ( $6 \mathrm{~h}$ after termination of eptifibatide infusion): normalisation of AUC in ASPItest and TRAPtest and no platelet transfusion required.
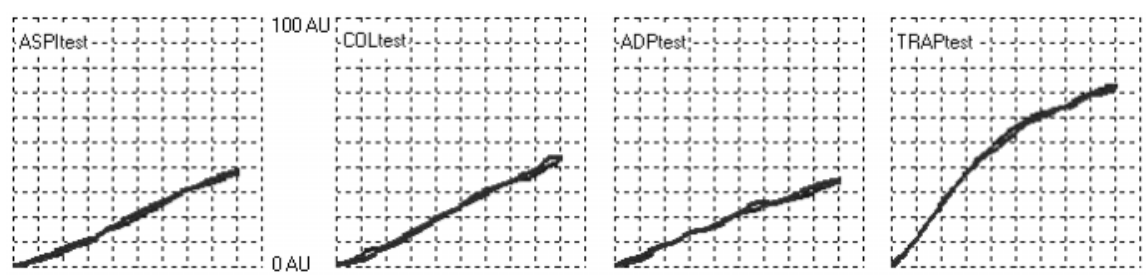

a a
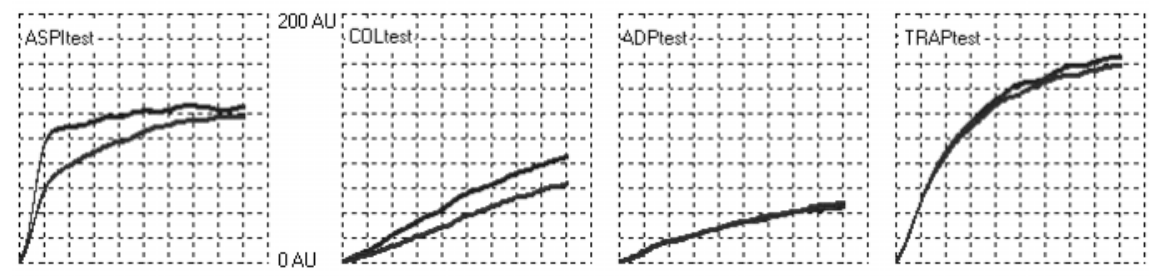

Area under the Curve : $863 \mathrm{AU} \mathrm{A}^{*} \mathrm{~min}$.

Area under the Curve : $333 \mathrm{AU}$ “min. Area under the Curve : $234 \mathrm{AU}$ "min.4rea under the Curve : $1006 \mathrm{AU}$ “min. gress 2007 in Hamburg [22, 96, 106, 117, 121, 138, 139] (fig. 3 , 4). This algorithm considers the following points:

- standardized questionnaire for bleeding and drug history,

- Multiplate analysis for evaluation of preoperative platelet function in case of clopidogrel pretreatment within the last 10 days (fig. 5, 6),

- prophylactic or therapeutic application of antifibrinolytics (fig. 7),

- ROTEM analysis after declamping of the aorta in order to predict the risk of bleeding even after protamine administration,

- optimizing the basic conditions for haemostasis (body temperature, $\mathrm{pH}$, haemoglobin level, ionised calcium concentration) before weaning from cardiopulmonary bypass [122, 131],

- optimizing of heparin reversal with protamine under consideration of ACT and ROTEM analysis [118, 119],

- ROTEM- and Multiplate-based coagulation management in case of diffuse bleeding even after protamine administration (fig. 8),

Cut-off values for therapeutic interventions recommended in this algorithm corresponds with the clinical experience of the participating clinics and are furthermore based on the results of the Multiplate study carried out by Rahe-Meyer et al. [96] in Hannover.

\section{ROTEM Triggers for Cardiac Surgery}

Based on our experience with ROTEM-based coagulation management in cardiac surgery we recommend the following cut-off values as triggers for therapeutic interventions in patients with diffuse bleeding [22, 106, 121]:

- $\mathrm{CLI}_{60 \mathrm{EX}}<85 \% \rightarrow$ aprotinin or tranexamic acid,
- $\mathrm{CT}_{\mathrm{IN}}>240 \mathrm{~s}$ and $\mathrm{CT}_{\mathrm{HEP}} / \mathrm{CT}_{\mathrm{IN}}<0.8 \rightarrow$ protamine,

- $\mathrm{CT}_{\mathrm{EX}}>90 \mathrm{~s}$ or $\mathrm{CT}_{\mathrm{HEP}}>280 \mathrm{~s} \rightarrow \mathrm{PCC}$ or FFP,

- $\mathrm{MCF}_{\mathrm{EX}} \leq 50 \mathrm{~mm}$ and $\mathrm{MCF}_{\mathrm{FIB}} \leq 12 \mathrm{~mm} \rightarrow$ fibrinogen concentrate (or cryoprecipitate),

- $\mathrm{MCF}_{\mathrm{EX}} \leq 50 \mathrm{~mm}$ and $\mathrm{MCF}_{\mathrm{FIB}}>12 \mathrm{~mm} \rightarrow$ platelet transfusion,

- $\mathrm{MCF}_{\mathrm{EX}}>50 \mathrm{~mm}$ and $\mathrm{MCF}_{\mathrm{FIB}}>12 \mathrm{~mm} \rightarrow$ check Multiplate! (Cave: Effects of antiplatelet drugs - like ASA and clopidogrel - cannot be detected by ROTEM analysis! Therefore, in these patients an additional Multiplate analysis should be performed),

- CLI60 $_{\mathrm{EX}}<88 \%$ and CLI60 $\mathrm{AP}<92 \%$ and CLI60 $\mathrm{XIII} \geq 95 \%$ $\rightarrow$ factor XIII concentrate,

- $\mathrm{CT}_{\mathrm{EX}}<80 \mathrm{~s}$ and $\mathrm{MCF}_{\mathrm{EX}}>60 \mathrm{~mm}$ and $\mathrm{MCF}_{\mathrm{FIB}}>16 \mathrm{~mm} \rightarrow$ consider administration of DDAVP, von Willebrand factor / factor VIII concentrate or rFVIIa.

\section{Multiplate Triggers for Platelet Transfusion in Cardiac Surgery}

In case of diffuse bleeding and ROTEM values within the normal range $\left(\mathrm{CT}_{\mathrm{EX}} \leq 90 \mathrm{~s}\right.$ and $\mathrm{CT}_{\mathrm{HEP}} \leq 280 \mathrm{~s}$ and $\mathrm{MCF}_{\mathrm{FIB}}>12$ $\mathrm{mm}$ and $\mathrm{MCF}_{\mathrm{EX}}>50 \mathrm{~mm}$ ) platelet function disorders have to be taken into account, particularly in regard to preoperative antiplatelet therapy or a cardiopulmonary bypass time of more than $3 \mathrm{~h}$. Therefore, in these patients an additional Multiplate analysis should be performed in order to appreciate the need for platelet transfusion. Under these conditions transfusion of platelets normally is indicated if Multiplate parameters fall below the following cut-off values $[12,96,106]$ (table 2):

- $\mathrm{AUC}_{\mathrm{ASPI}}<200 \mathrm{AU} \times$ min or

- AUC $_{\mathrm{COL}}<200 \mathrm{AU} \times$ min or

- $\mathrm{AUC}_{\mathrm{ADP}}<300 \mathrm{AU} \times$ min or

- $\mathrm{AUC}_{\mathrm{TRAP}}<500 \mathrm{AU} \times \min$. 


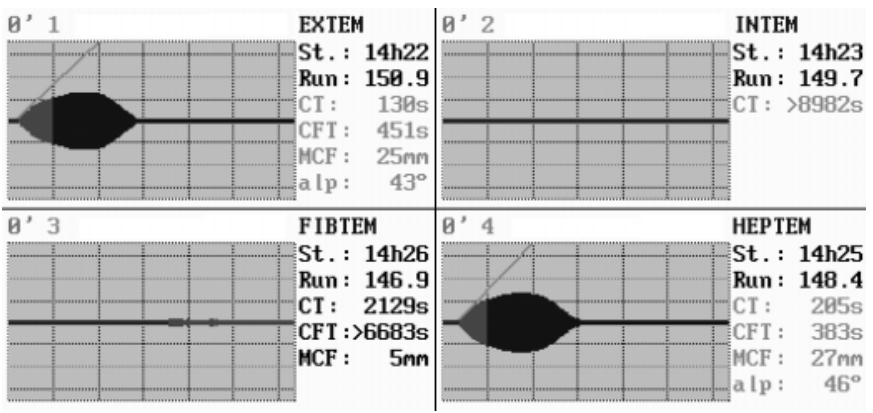

Fig. 7. Detection of fulminant hyoperfibrinolysis $\left(\mathrm{CLI} 30_{\mathrm{EX}}=0 \%\right)$ and subsequent hypofibrinogenaemia $\left(\mathrm{MCF}_{\mathrm{FIB}}=5 \mathrm{~mm}\right)$ in ROTEM analysis during cardiopulmonary bypass.

Impact of the ROTEM- and Multiplate-Based Coagulation Management on the Intraoperative Usage of Blood Components in the Cardiac Surgery of the University Clinic of Essen

In context with our POC coagulation management the overall intraoperative usage of blood components in cardiac surgery could be reduced by $34 \%$ within 2 years (from 2004 to 2006). Regarding the several blood components the reduction is distributed as follows:

- PRBC: reduction from 3,276 to 2,599 transfused units $(-21 \%)$,

- FFP: reduction from 1,986 to 613 transfused units $(-69 \%)$,

- PC: increase from 336 to 485 transfused units $(+44 \%)$.

In contrast to our results in liver transplantation, a reduction in usage of PC could not be realised in cardiac surgery [7]. The increase in $\mathrm{PC}$ consumption probably is induced by a growing number of patients with a combined ASA and clopidogrel therapy $[60,63,64,68]$.

Overall the reduction in transfusion requirements in cardiac surgery resulted in cost saving of EUR 110,913.00 per year. However, these economy savings were in part balanced by an increase in costs for fibrinogen concentrate. A remarkable increase in the usage of PCC concentrate could not be noticed in context with this new strategy. An exact analysis of the efficiency and economy of a ROTEM- and Multiplate-based POC coagulation management in cardiac surgery is the subject of a projected pharmaco-economic study. In this context, inherent consequential costs shall be taken into account, e.g. TRALI, TACO, sepsis, ventilation time and stay at intensive care unit (ICU) and at hospital. In a pilot study including 10 patients with aortic arch replacement because of acute type A

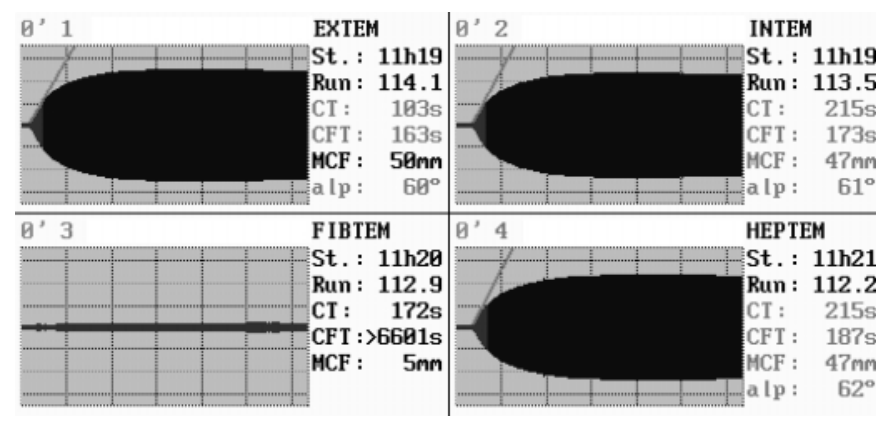

Fig. 8. Secondary bleeding at ICU after aortocoronary bypass grafting in a patient with clopidogrel pretreatment. Identification of hypofibrinogenaemia in ROTEM analysis $\left(\mathrm{MCF}_{\mathrm{FIB}}=5 \mathrm{~mm}\right)$ as the cause of bleeding. After substitution with $4 \mathrm{~g}$ fibrinogen concentrate bleeding stopped and no re-exploration was required.

aortic dissection, a significant reduction in postoperative FFP usage and perioperative costs for blood components and coagulation factor concentrates could be demonstrated. Furthermore, a trend to a reduced postoperative ventilation time and a shortened stay at the ICU and hospital could be shown in this small population $[120,127,128]$.

In summary, POC coagulation management based on the combined use of thrombelastometry (ROTEM) and platelet function analyzers (PFA-100 and/or Multiplate) is helpful in predicting bleeding complications in cardiac surgery. Furthermore, this combination may be applicable for risk estimation for postoperative thromboembolic events. Moreover, coupled with therapeutic algorithms for control of platelet transfusion and therapy with rapidly available and highly effective coagulation factor concentrates, they provide the possibility to reduce transfusion requirements and costs.

\section{Conflict of Interest}

The authors point at associations with the following companies: Dr. Görlinger held scientific lectures on fee basis for Pentapharm $\mathrm{GmbH}(\mathrm{Mu}-$ nich, Germany), Instrumentation Laboratory (Kirchheim, Germany), Diagnostica Stago (Asnières sur Seine, France), and CLS Behring GmbH (Marburg, Germany).

\section{Ethical and Legal Prerequisites}

All studies carried out in Essen and Hannover involved in this paper have been approved by an ethical committee and thus meets the standards of the Declaration of Helsinki in its revised version of 1975 and its amendments of 1983, 1989, and 1996. 


\section{References}

1 Levy JH, Tanaka KA, Steiner ME: Evaluation and management of bleeding during cardiac surgery. Curr Hematol Rep 2005;4:368-372.

$\checkmark 2$ Despotis GJ, Goodnough LT: Management approaches to platelet-related microvascular bleeding in cardiothoracic surgery. Ann Thorac Surg 2000;70 (suppl):S20-S32.

3 Calatzis A, Heesen M, Spannagl M: Patientennahe Sofortdiagnostik von Hämostasestörungen in der Anästhesie und Intensivmedizin. Anaesthesist 2003;52:229-237.

4 Sié P, Steib A: Central laboratory and point of care assessment of perioperative hemostasis. Can J Anest 2006;53(suppl):S12-S20.

5 Despotis GJ, Skubas NJ, Goodnough LT: Optimal management of bleeding and transfusion in patients undergoing cardiac surgery. Semin Thorac Cardiovasc Surg 1999;11:84-104.

6 Goodnough LT, Despotis GJ: Future directions in utilization review: the role of transfusion algorithms. Transfus Sci 1998;19:97-105.

7 Görlinger K, Dirkmann D, Hanke AA, Adamzik $\mathrm{M}$, Peters J: Inpact of ROTEM ${ }^{\circledR}$-based coagulation management on usage of blood components and cost saving in LTX. Anesthesiology 2007;107: A2124.

8 Karkouti K, Wijeysundera DN, Yau TM, Beattie WS, Abdelnaem E, McCluskey SA, Ghannam M, Yeo E, Djaiani G, Karski J: The independent association of massive blood loss with mortality in cardiac surgery. Transfusion 2004;44:1453-1462.

9 Dzik S: Non-infectious serious hazards of transfusion. Blood Bull 2002;5:1-2.

10 Gajic O, Gropper MA, Hubmayr RD: Pulmonary edema after transfusion: how to differentiate transfusion-associated circulatory overload from transfusion-related acute lung injury. Crit Care Med 2006;34(suppl):S109-S113.

11 Hambly PR, Dutton RP: Excess mortality associated with the use of a rapid infusion system at a level 1 trauma center. Resuscitation 1996;31:127-133.

12 Popovsky MA: Pulmonary consequences of transfusion: TRALI and TACO. Transfus Apher Sci 2006;34:243-244.

13 SHOT Annual Report 2005: Serious hazards of transfusion. www.shotuk.org/SHOT\%20report $\%$ 202005.pdf.

14 Wallis JP, Dzik S: Is fresh frozen plasma overtransfused in the United States? Transfusion 2004;44: 1674-1675.

15 Spiess BD: Transfusion of blood products affects outcome in cardiac surgery. Semin Cardiothorac Vasc Anesth 2004;8:267-281.

16 Spiess BD, Royston D, Levy JH, Fitch J, Dietrich W, Body S, Murkin J, Nadel A: Platelet transfusions during coronary artery bypass graft surgery are associated with serious adverse outcomes. Transfusion 2004;44:1143-1148.

17 Karkouti K, Wijeysundera DN, Yau TM, Callum JL, Meineri M, Wasowicz M, McCluskey SA, Beattie WS: Platelet transfusions are not associated with increased morbidity or mortality in cardiac surgery. Can J Anaesth 2006;53:279-287.

18 Morrow JF, Braine HG, Kickler TS, Ness PM, Dick JD, Fuller AK: Septic reactions to platelet transfusions. A persistent problem. JAMA 1991;266: 555-558.

19 Ness P, Braine H, King K, Barrasso C, Kickler T, Fuller A, Blades N: Single-donor platelets reduce the risk of septic platelet transfusion reactions. Transfusion 2001;41:857-861.
20 Yomtovian R, Lazarus HM, Goodnough LT, Hirschler NV, Morrissey AM, Jacobs MR: A prospective microbiologic surveillance program to detect and prevent the transfusion of bacterially contaminated platelets. Transfusion 1993;33:902909

21 Fries D, Haas T, Velik-Salchner C, Lindner K, Innerhofer P: Gerinnungsmanagement beim Polytrauma. Anaesthesist 2005;54:137-144.

22 Görlinger K: Coagulation management during liver transplantation. Hämostaseologie 2006;26(suppl 1): S64-S75.

23 Hartmann M, Sucker C, Boehm O, Koch A, Loer S, Zacharowski K: Effects of cardiac surgery on hemostasis: Transfus Med Rev 2006;20:230-241.

24 Paparella D, Brister SJ, Buchanan MR: Coagulation disorders of cardiopulmonary bypass: a review. Intensive Care Med 2004;30:1873-1881

25 Schoechl H: Coagulation management in major trauma: Hämostaseologie 2006;26(suppl 1):S50S55.

26 Brilakis ES, Banerjee S, Berger PB: Perioperative management of patients with coronary stents. J Am Coll Cardiol 2007;49:2145-2150.

27 Bundesärztekammer: Leitlinien zur Therapie mit Blutkomponenten und Plasmaderivaten, 3., überarbeitete Aufl. Köln, Deutscher Ärzte-Verlag, 2003.

28 Greinacher A, Kiefel V, Klüter H, Kroll H, Pötzsch B, Riess H: Empfehlungen zur Thrombozytentransfusion der Thrombozyten-Arbeitsgruppe der DGTI, GTH und DGHO. Transfus Med Hemother 2006;33:528-543.

29 Jurk K, Kehrel BE: Inherited and acquired disorders of platelet function. Transfus Med Hemother 2007;34:6-19.

30 Anderson L, Quasim I, Soutar R, Steven M, Macfie A, Korte W: An audit of red cell and blood product use after the institution of thromoelastometry in a cardiac intensive care unit. Transfus Med 2006;16: 31-39.

31 Avidan MS, Alcock EL, Da Fonseca J, Ponte J, Desai JB, Despotis GJ, Hunt BJ: Comparison of structured use of routine laboratory tests or nearpatient assessment with clinical judgement in the management of bleeding after cardiac surgery. Br J Anaesth 2004;92:178-186.

32 Despotis GJ, Joist JH, Goodnough LT: Monitoring of hemostasis in cardiac surgical patients: impact of point-of-care testing on blood loss and transfusion outcomes. Clin Chem 1997;43:1684-1696.

33 Shore-Lesserson L, Manspeizer HE, DePerio M, Francis S, Vela-Cantos F, Ergin MA: Throboelastography-guided transfusion algorithm reduces transfusions in complex cardiac surgery. Anesth Analg 1999;88:312-319.

34 Spalding GJ, Hartrumpf M, Sierig T, Oesberg N, Kirschke CG, Albes JM: Cost reduction of perioperative coagulation management in cardiac surgery: value of 'bedside' thrombelastography (ROTEM). Eur J Cardiothorac Surg 2007;31:1052-1057.

35 Klouche M: Diagnostic methods for platelet function analysis. Transfus Med Hemother 2007;34: 20-32.

36 Asaf T, Reuveni H, Yermiahu T, Leiberman A, Gurman G, Porat A, Schlaeffer P, Shifra S, Kapelushnik J: The need for routine pre-operative coagulation screening tests (prothrombin time PT/partial thromboplastin time PTT) for healthy children undergoing elective tonsillectomy and/or adenoidectomy. Int $\mathrm{J}$ Pediatr Otorhinolaryngol 2001;61:217-222.
7 Dzik WH: Predicting hemorrhage using preoperative coagulation screening assays. Curr Hematol Rep 2004;3:324-330.

38 Eberl W, Wendt I, Schroeder HG: Präoperatives Screening auf Gerinnungsstörungen vor Adenotomie und Tonsillektomie. Klin Pädiatr 2005;217: 20-24.

39 Munro J, Booth A, Nicholl J: Routine preoperative testing: a systematic review of the evidence. Health Technol Assess 1997:1:1-62.

40 Velanovich V: The value of routine preoperative laboratory testing in predicting postoperative complications: a multivariate analysis. Surgery 1991; 109:236-243.

41 Kitchens CS: To bleed or not to bleed? Is that the question for the PTT? J Thromb Haemost 2005;3: 2607-2611.

42 Franchini M, Zugni C, Veneri D, Gandini G, Lipp G, Manzato F, Brazzarola P: High prevalence of acquired von Willebrand's syndrome in patients with thyroid diseases undergoing thyroid surgery. Haematologica 2004;89:1341-1346.

43 Homoncik M, Gessl A, Ferlitsch A, Jilma B, Vierhapper $\mathrm{H}$ : Altered platelet plug formation in hyperthyroidism and hypothyroidism. J Clin Endocrinol Metab 2007;92:3006-3012.

44 Klouche M: Cellular haemostaseology - diagnosis and therapeutic monitoring of inherited and acquired functional platelet disorders. Transfus Med Hemother 2007:34:4-5

45 Lee A, Chui PT, Aun CS, Lau AS, Gin T: Incidence and risk of adverse perioperative events among surgical patients taking traditional Chinese herbal medicines. Anesthesiology 2006;105:454-461.

46 Michiels JJ, Schroyens W, Berneman Z, van der Planken M: Acquired von Willebrand syndrome type 1 in hypothyroidism: reversal after treatment with thyroxine. Clin Appl Thromb Hemost 2001;7: 113-115.

47 Rott H, Halimeh S, Kappert G, Trobisch H: Most unexpected bleeding complications during or after surgery in German patients occur due to acquired aspirin-related thrombocytopathia or von Willebrands disease. 27th WFH World Congress of Hemophilia; Vancouver, Canada, May 21-25, 2006.

48 Silwer J: von Willebrand disease in Sweden. Acta Paediatr Scand Suppl 1973;238:1-159.

49 Vincentelli A, Susen S, Le Tourneau T, Six I, Fabre O, Juthier F, Bauters A, Decoene C, Goudemand J, Prat A, Jude B: Acquired von Willebrand syndrome in aortic stenosis. N Engl J Med 2003;349: 343-349.

50 Gerlach R, Tolle F, Raabe A, Zimmermann M, Siegemund A, Seifert V: Increased risk for postoperative hemorrhage after intracranial surgery in patients with decreased factor XIII activity: implications of a prospective study. Stroke 2002;33: 1618-1623.

51 Korte W: Fibrin monomer and factor XIII: a new concept for unexplained intraoperative coagulopathy. Haemostaseologie 2006;26(suppl 1):S30-S35.

52 Wettstein P, Haeberli A, Stutz M, Rohrer M, Corbetta C, Gabi K, Schnider T, Korte W: Decreased factor XIII availability for thrombin and early loss of clot firmness in patients with unexplained intraoperative bleeding. Anesth Analg 2004;99: 1564-1569. 
53 Charbit B, Mandelbrot L, Samain E, Baron G, Haddaoui B, Keita H, Sibony O, Mahieu-Caputo D, Hurtaud-Roux MF, Huisse MG, Denninger MH, de Prost D, for the PPH Study Group: The decrease of fibrinogen is an early predictor of the severity of postpartum hemorrhage. J Thromb Haemost 2007 5:266-273.

54 Koscielny J, Ziemer S, Radtke H, Schmutzler M, Pruss A, Sinha P, Salama A, Kiesewetter H, Latza $\mathrm{R}$ : A practical concept for preoperative identification of patients with impaired primary hemostasis. Clin Appl Thromb Hemost 2004;10:195-204.

55 Koscielny J, Kiesewetter H, von Tempelhoff GF: More on: platelet function analyzer (PFA) $-100^{\circledR}$ closure time in the evaluation of platelet disorders and platelet function. J Thromb Hemost 2006;4: 1426-1427.

56 Koscielny J, von Tempelhoff GF, Ziemer S, Radtke H, Schmutzler M, Sinha P, Salama A, Kiesewetter H, Latza R: A practical concept for preoperative management of patients with impaired primary hemostasis. Clin Appl Thromb Hemost 2004;10: $155-166$.

57 Roschitz B, Thaller S, Koestenberger M, Wirnsberger A, Leschnik B, Fritsch P, Muntean W: PFA100 closure time in preoperative screening in 500 pediatric patients. Thromb Haemost 2007;98: 243-247.

58 Pfanner G, Koscielny J, Pernerstorfer T, Gütl M, Perger P, Fries D, Hofmann N, Innerhofer P, Kneifl W, Neuner L, Schöchl H, Kozek-Langenecker SA: Präoperative Blutungsanamnese. Empfehlungen der Arbeitsgruppe perioperative Gerinnung der Österreichischen Gesellschaft für Anästhesiologie, Reanimation und Intensivmedizin. Anästhesist 2007;56:604-611.

59 Strauß J, Becke K, Schmidt J: Gerinnungsstörungen: Auf die Anamnese kommt es an. Dtsch Ärztebl 2006;103:A1948.

60 Chu MW, Wilson SR, Novick RJ, Stitt LW, Quantz MA: Does clopidogrel increase blood loss following coronary artery bypass surgery? Ann Thorac Surg 2004;78:1536-1541.

61 Eisenstein EL, Anstorm KJ, Kong DF, Shaw LK, Tuttle RH, Mark DB, Kramer JM, Harrington RA, Matchar DB, Kandzari DE, Peterson ED, Schulman KA, Califf RM: Clopidogrel use and longterm clinical outcomes after drug-eluting stent implantation. JAMA 2007;297:159-168.

62 Iakovou I, Schmidt T, Bonizzoni E, Ge L, Sangiorgi GM, Stankovic G, Airoldi F, Chieffo A, Montorfano M, Carlino M, Michev I, Corvaja N, Briguori C, Gerckens U, Grube E, Colombo A: Incidence, predictors, and outcome of thrombosis after successful implantation of drug-eluting stents. JAMA 2005;293:2126-2130.

-63 Khurram Z, Chou E, Minutello R, Bergman G, Parikh M, Naidu S, Wong SC, Hong MK: Combination therapy with aspirin, clopidogrel and warfarin following coronary stenting is associated with significant risk of bleeding. J Invasive Cardiol 2006; 18:162-164.

64 Leong JY, Baker RA, Shah PJ, Cherian VK, Knight JL: Clopidogrel and bleeding after coronary artery bypass graft surgery. Ann Thorac Surg 2005;80: 928-933.

65 Pfisterer M, Brunner-La Rocca HP, Buser PT, Rickenbacher P, Hunziker P, Mueller C, Jeger R, Bader F, Osswald S, Kaiser C, for the BASKETLATE Investigators: Late clinical events after clopidogrel discontinuation may limit the benefit of drug-eluting stents: an observational study of drugeluting versus bare-metal stents. J Am Coll Cardiol 2006;48:2584-2591.
66 Pinto Slottow TL, Waksman R: Overview of the 2006 Food and Drug Administration Circulatory System Devices Panel meeting on drug-eluting stent thrombosis. Catheter Cardiovasc Interv 2007; 69:1064-1074.

67 Ray JG, Deniz S, Olivieri A, Pollex E, Vermeulen MJ, Alexander KS, Cain DJ, Cybulsky I, Hamielec $\mathrm{CM}$ : Increased blood product use among coronary artery bypass patients prescribed preoperative spirin and clopidogrel. BMC Cardiovasc Disord 2003;3:3.

68 von Heymann C, Redlich U, Moritz M, Sander M, Vargas Hein O, Grubitzsch H, Konertz WF, Spies C: Aspirin and clopidogrel taken until 2 days prior to coronary artery bypass graft surgery is associated with increased postoperative drainage loss. Thorac Cardiovasc Surg 2005;53:341-345.

69 Yende S, Wunderink RG: Effect of clopidogrel on bleeding after coronary artery bypass surgery. Crit Care Med 2001;29:2271-2275.

70 Favaloro EJ, Facey D; Henniker A: Use of a novel patelet function analyzer (PFA-100) with high sensitivity to disturbances in von Willebrand factor to screen for von Willebrand's disease and other disorders. Am J Hematol 1999;62:165-174.

71 Mammen EF, Comp PC, Gosselin R, Greenberg C, Hoots WK, Kessler CM, Larkin EC, Liles D, Nugent DJ: PFA-100 system: a new method for assessment of platelet dysfunction. Semin Thromb Hemost 1998;24:195-202.

72 Wuillemin WA, Gasser KM, Zeerleder SS, Lämmle B: Evaluation of a platelet function analyser (PF$100)$ in patients with a bleeding tendency. Swiss Med Wkly 2002;132:443-448.

73 Favaloro EJ, Kershaw G, Bukuya M, Hertzberg M, Koutts J: Laboratory diagnosis of von Willebrand disorder (vWD) and monitoring of DDAVP therapy: efficacy of the PFA-100 and vWF:CBA as combined diagnostic strategies. Haemophilia 2001;7: 180-189.

74 Lasne D, Fiemeyer A, Chatellier G, Chammas C, Baron JF, Aiach M: A study of platelet functions with a new analyzer using high shear stress (PFA $100)$ in patients undergoing coronary artery bypass graft. Thromb Haemost 2000;84:794-799.

75 Franchini M: The use of desmopressin as a hemostatic agent: a concise review. Am J Hematol 2007; 82:731-735.

76 Cammerer U, Dietrich W, Rampf T, Braun SL, Richter JA: The predictive value of modified computerized thromoelastography and platelet function analysis for postoperative blood loss in routine cardiac surgery. Anesth Analg 2003;96:51-57.

77 Fattorutto M, Pradier O, Schmartz D, Ickx B, Barvais L: Does the platelet function analyser (PFA100) predict blood loss after cardiopulmonary bypass? Br J Anaesth 2003;90:692-693.

78 Hertfelder HJ, Bös M, Weber D, Winkler K, Hanfland P, Preusse CJ: Perioperative monitoring of primary and secondary hemostasis in coronary artery bypass grafting. Semin Thromb Hemost 2005;31:426-440.

79 Gum PA, Kottke-Marchant K, Poggio ED, Gurm H, Welsh PA, Brooks L, Sapp SK, Topol EJ: Profile and prevalence of aspirin resistance in patients with cardiovascular disease. Am J Cardiol 2001;88: 230-235.

80 Gum PA, Kottke-Marchant K, Welsh PA, White J, Topol EJ: A prospective, blinded determination of the natural history of aspirin resistance among stable patients with cardiovascular disease. J Am Coll Cardiol 2003;41:961-965.
1 Chakroun T, Gerotziafas G, Robert F, Lecrubier C, Samama MM, Hatmi M, Elalamy I: In vitro aspirin resistance detected by PFA- $100^{\circledR}$ closure time: pivotal role of plasma von Willebrand factor. $\mathrm{Br} \mathrm{J}$ Haematol 2004;124:80-85.

82 Niggemeier M: Diagnostik der Thrombozytenfunktion unter Zusatz der Glykoprotein-IIb/IIIa-Rezeptorantagonisten Tirofiban - Vergleich der «Point of Care» Verfahren Thrombelastographie, Impedanzaggregometrie und «Platelet Function Analyser» (PFA-100) bei verschiedenen Tirofibankonzentrationen. Dissertation Heinrich-HeineUniversität Düsseldorf 2004. http://docserv.uniduesseldorf.de/servlets/DocumentServlet id $=2944$.

83 Geiger J, Teichmann L, Grossmann R, Aktas B, Steigerwald U, Walter U, Schinzel R: Monitoring of clopidogrel action: comparison of methods. Clin Chem 2005;51:957-965.

84 Grau AJ, Reiners S, Lichy C, Buggle F, Ruf A Platelet function under aspirin, clopidogrel, and both after ischemic stroke: a case-crossover study. Stroke 2003;34:849-854.

85 Mani H, Linnemann B, Luxembourg B, Kirchmayr $\mathrm{K}$, Lindhoff-Last E: Response to aspirin and clopidogrel monitored with different platelet function methods. Platelets 2006;17:303-310.

86 Calatzis A, Theisen F, Reininger AJ, Spannagl M: Monitoring of clopidogrel using multiple electrode aggregometry. Blood 2006;108:A883.

87 Calatzis A, Rahe-Meyer N, Theisen F, Spannagl M: Erfassen der Wirkungen von Aspirin und Clopidogrel durch Multiple Elektroden Aggregometrie. Deutscher Anästhesiekongress 2007, Hamburg, 5.-8. Mai 2007: PO 4.6.1.

88 Ivandic BT, Schlick P, Staritz P, Kurz K, Katus HA Giannitsis E: Determination of clopidogrel resistance by whole blood platelet aggregometry and inhibitors of the P2Y12 receptor. Clin Chem 2006; 52:383-388.

89 Mueller T, Dieplinger B, Poelz W, Calatzis A, Haltmayer M: Utility of whole blood impedance aggregometry for the assessment of clopidogrel action using the novel Multiplate ${ }^{\circledR}$ analyzer - comparison with two flow cytometric methods. Thromb Res 2007;4:DOI 10.1016/j.thromres.2007.03.022.

90 Sucker C, Kurt M, Lithmathe J, Feindt P, Zotz RB, Scharf RE: High-prevalence of prolonged closure times in the presence of aortic-valve stenosis: association with perioperative transfusion requirements. Transfus Med Hemother 2006;33(suppl 1): 19.

91 Hayward CP, Harrison P, Cattaneo M, Ortel TL, Rao AK, for the Platelet Physiology Subcommittee of the Scientific and Standardization Committee of the International Society on Thrombosis and Haemostasis: Platelet function analyzer (PFA)-100 closure time in the evaluation of platelet disorders and platelet function. J Thromb Haemost 2006;4 312-319.

92 Karger R, Donner-Banzhoff N, Müller HH, Kretschmer V, Hunik M: Diagnostic performance of the platelet function analyzer (PFA-100) for the detection of disorders of primary haemostasis in patients with a bleeding history - a systemic review and metaanalysis. Platelets 2007:18:249-260.

93 Calatzis A, Witwer B, Krueger: A new approach to platelet function analysis in whole blood - the Multiplate analyser. Platelets 2004;15:479-517.

94 Toth O, Calatzis A, Penz S, Losonczy H, Siess W: Multiple electrode aggregometry: a new device to measure platelet aggregation in whole blood. Thromb Haemost 2006;96:781-788. 
95 Jambor C, Weber C, Gerhardt K, Preibisch D, Zwißler B: Point of care measuring of platelet aggregation with the novel impedance aggregometer Multiplate - the optimal preanalytical conditions required. Deutscher Anästhesiekongress 2007. Hamburg, 5.-8. Mai 2007: PO 4.6.8.

96 Rahe-Meyer N, Gilde I, Calatzis A: Multiple electrode aggregometry is a predictive marker of transfusion requirements during open heart surgery. Hämostaseologie 2006;26:A78.

97 Rahe-Meyer N, Winterhalter M, Boden A, Solomon C, Weilbach C, Piepenbrock S, Calatzis A: Veränderungen der Thrombozytenaggregation im Vollblut während aotokoronaren Bypass-Operationen: Einfluss der Stimulantien. Deutscher Anästhesiekongress 2007, Hamburg, 5.-8. Mai 2007: PO 4.6.6.

98 Calatzis A, Spannagl M, Loreth R: Multiplate ${ }^{\circledR}$ platelet function analysis - application and interpretation. 2007. www.multiplate.net.

99 Seyfert UT, Haubelt H, Vogt A, Hellstern P: Variables influencing Multiplate whole blood impedance platelet aggregometry and turbidimetric platelet aggregation in healthy individuals. Platelets 2007;18:199-206.

100 Calatzis A, von Pape KW, Reininger AJ, Theisen F, Spannagl M: Prevalence of aspirin non-response in out-patients and in-patients as determined by multiple electrode aggregometry. Blood 2006;108: A879.

101 Von Pape KW, Dzijan-Horn M, Bohner J, Spannagl $\mathrm{M}$, Weisser $\mathrm{H}$, Calatzis A: Control of aspirin effect in chronic cardiovascular patients using two whole blood platelet function assays: PFA-100 and multiple electrode aggregometry. 36th Hemophilia Symposium 2005, Hamburg.

102 Kalb M, Scharbert G, Kress HG, Marschalek C, Kozek S: Monitoring of the reversing effect of desmopression on cyclooxygenase-I-induced platelet inhibition. Anesthesiology 2005;103:A394.

103 Wittmann G, Romann A, Conell B, Becker G, Calatzis A, Schramm W: Functional quality control of platelet concentrates using multiple electrode aggregometry. 50th Annual Meeting of the Society of Thrombosis and Haemostasis Research 2006, Basel, February 15-18, 2006: P363.

104 Poston R, Gu J, Manchio J, Lee A, Brown J, Gammie J, White C, Griffith BP: Platelet function tests predict bleeding and thrombotic events after offpump coronary bypass grafting. Eur J Cardiothorac Surg 2005;27:584-591.

105 Inglott S, Burgess C, Liesner R, Khair K: The evaluation of impedance aggregometry to measure response to ristocetin in children with type I von Willebrand disease pre and post intranasal DDAVP: Haemophilia 2006;12(suppl 2):30 (PO 903).

106 Görlinger K, Jambor C, Hanke A, Adamzik M, Hartmann M, Rahe-Meyer N: Thrombelastometry and impedance aggregometry based algorithm for coagulation management in cardiac surgery. Intensive Care Med 2007:33:(accepted for publication)

107 Calatzis A, Fritzsche P, Calatzis A, Kling M, Hipp R, Stemberger A: roTEG Coagulation Analyzer Ein neues System zur intraoperativen BedsideGerinnungsdiagnostik. Anaesthesist 1995;44:491.

108 Hartert H: Blutgerinnungsstudien mit der Thrombelastographie, einem neuen Untersuchungsverfahren. Klin Wochenschr 1948;26: 577-583.

109 Calatzis A, Fritzsche P, Calatzis A, Kling M, Hipp $\mathrm{R}$, Stemberger A: A comparison of the technical principle of the roTEG Coagulation Analyser and conventional thrombelastographic systems. Ann Hematol 1996;72(suppl 1):142-146.
110 Lang T, von Depka M: Possibilities and limitations of thrombelastometry/graphy. Hämostaseologie 2006;23(suppl 1):S20-S29.

111 Kettner SC, Panzer OP, Kozek SA, Seibt FA, Stoiser B, Kofler J, Locker GJ, Zimpfer M: Use of abciximab-modified thrombelastography in patients undergoing cardiac surgery. Anesth Analg 1999;89:580-584

112 Lang T, Toller W, Gütl M, Mahla E, Metzler H, Rehak P, März W, Halwachs-Baumann G: Different effects of abciximab and cytochalasin D on clot strength in thrombelastography. J Thromb Haemost 2004;2:147-153.

113 Görlinger K, Lier H, Vorweg M: Diagnose-Algorithmus der «Essener Runde» - Thrombelastometrie mittels ROTEM ${ }^{\circledR}$. 2006. www.essener-runde. de

114 Görlinger K: ROTEM ${ }^{\circledR}$ - Erweitertes perioperatives Gerinnungsmanagement. J Anästh Intensivbeh 2005;12:53-58.

115 Görlinger K: Klinischer Stellenwert der Point of Care Diagnostik bei akuter Blutung. Deutscher Anästhesiekongress 2006, Leipzig, 17.-20. Mai 2006: H-102.3.

116 Spiel AO, Mayr FB, Firbas C, Quehenberger P, Jilma B: Validation of rotational thrombelastography in a model of systemic activation of fibrinolysis and coagulation in humans. J Thromb Haemost 2006;4:411-416

117 Duchemin G, Kiss G, Gueret G, Rossignol B, Corre O, Kerautret P, Blouch MT, Abgrall JF, Görlinger K, Arvieux: Difference between MCFExTEM and MCF-FibTEM (ROTEM) and platelet activity after cardiopulmonary bypass. Eur J Anaesth 2006;23(suppl 37):85.

118 Mittermayr M, Margreiter J, Velik-Salchner C, Klingler A, Streif W, Fries D, Innerhofer P: Effects of protamine and heparin can be detected and easily differentiated by modified thrombelastography $\left(\right.$ ROTEM $\left.^{\circledR}\right)$ : an in vitro study. Br J Anaest 2005; 95:310-316.

119 Cho KH, Woo S, Hur CH, Sung KS, Kim MC: Comparative study of heparinase treated activated clotting time with heparinase treated thrombelastography for detecting residual heparin effects following cardiopulmonary bypass. Korean J Anesthesiol 1995;29:850-857.

120 Görlinger K, Hanke A, Kottenberg-Assenmacher E, Herold U, Hartmann M: ROTEM ${ }^{\circledR}$-basiertes Gerinnungsmanagement bei einem 75 Jahre alten Patienten mit Aortenbogenersatz bei Typ AAortendissektion. Deutscher Anästhesiekongress 2007, Hamburg, 5.-8. Mai 2007: PO 4.6.8.

121 Görlinger K, Jambor C, Hanke A, Kottenberg-Assenmacher E, Adamzik M, Hartmann M, RaheMeyer N: ROTEM ${ }^{\circledR}$ - and Multiplate ${ }^{\circledR}$-basierter Algorithmus zum Point-of-Care-Gerinnungsmanagement in der Herzchirurgie. Deutscher Anästhesiekongress 2007, Hamburg, 5.-8. Mai 2007: PO 4.6.3.

122 Dirkmann D, Hanke AA, Görlinger K, Peters J: Influence of hypothermia and acidosis on whole blood coagulation studied by thrombelastometry. Anesthesiology 2007;107:A546.

123 Mousa SA, Forsythe MS: Comparison of the effect of different platelet GPIIb/IIIa antagonists on the dynamics of platelet/fibrin-mediated clot strength induced using thrombelastography. Thromb Res 2001;104:49-56.

124 Spiess BD, Tuman KJ, McCarthy RJ, DeLaria GA, Schillo R, Ivankovich AD: Thrombelastography as an indicator of post-cardiopulmonary bypass coagulopathies. J Clin Monitoring Computing 1987; 3:1387-1397.
125 Lösche W, Reinhöfer M, Macholdt C, Franke U, Brauer M, Barz D, Reinhart K, Marx G: Use of ROTEM $^{\circledR}$ thrombelastometry to monitor peri-operative haemostasis in patients with on-pump cardiac surgery. Intensivmedizin 43(suppl 1):23-24.

126 Reinhöfer M, Lösche W, Marx G, Barz D: Perioperative haemostatic management - thrombelastometry in cardiac surgery. Transfus Med Hemother 2006;33(suppl 1):20.

127 Görlinger K, Herold U, Jakob H, Hanke AA ROTEM-based coagulation management in acute type A aortic dissection: medical and economical aspects. J Anäst Intensivbeh 2007;14:(accepted for publication).

128 Hanke AA, Herold U, Jakob H, Görlinger K: Rotational thrombelastometry based coagulation management in acute type A aortic dissection. Anesthesiology 2007;107:A544.

129 McCrath DJ, Cerboni E, Frumento RJ, Hirsh AL, Bennett-Guerrero E: Thromboelastography maximum amplitude predicts postoperative thrombotic complications including myocardial infarction. Anesth Analg 2005;100:1576-1583.

130 Spiess BD, Gillies BS, Chandler W, Verrier E: Changes in transfusion therapy and reexploration rate after institution of a blood management program in cardiac surgical patients. J Cardiothorac Vasc Anesth 1995;9:168-173

131 Lier H, Kampe S, Schröder S: Rahmenbedingungen für eine intakte Hämostase. Anaesthesist 2007:56:239-251.

132 Wolberg AS, Meng ZH, Monroe DM, Hoffman M: A systematic evaluation of the effect of temperature on coagulation enzyme activity and platelet function. J Trauma 2004;56:1221-1228.

133 Williams MS, Ng'alla LS: Heparin therapy leads to platelet activation and prolongation of PFA-100 closure time. J Cardiovasc Pharmacol Ther 2005; 10:273-280.

134 Jordan A, David T, Homer-Vanniasinkam S, Graham A, Walker P: The effects of margination and red cell augmented platelet diffusivity on platelet adhesion in complex flow. Biorheology 2004;41: 641-653.

135 Valeri CR, Cassidy G, Pivacek LE, Ragno G Lieberthal W, Crowley JP, Khuri SF, Loscalzo J Anemia-induced increase in the bleeding time: implications for treatment of nonsurgical blood loss. Transfusion 2001;41:977-983.

136 Nuttall GA, Olivier WC, Santrach PJ, Bryant S, Dearani JA, Schaff HV, Ereth MH: Efficacy of a simple intraoperative transfusion algorithm for nonerythrocyte component utilization after cardiopulmonary bypass. Anesthesiology 2001;94: 773-781.

137 Karkouti K, Yau TM, Rensburg A, McCluskey SA, Callum J, Wijeysundera DN, Beattie WS: The effects of a treatment protocol for cardiac surgical patients with exessive blood loss on clinical outcomes. Vox Sang 2006;91:148-156.

138 Görlinger K, Kiss G, Dirkmann D, Dusse F, Hanke A, Arvieux CC, Peters J: ROTEM ${ }^{\circledR}$-based algorithm for management of acute haemorrhage and coagulation disorders in trauma patients. Eur J Anaesth 2006;23(suppl 37):84-85.

139 Görlinger K, Dirkmann D, Kiss G, Dusse F, Hanke A, Arvieux CC, Peters J: ROTEM ${ }^{\circledR}$-based management for diagnosis and treatment of acute haemorrhage during liver transplantation. Eur J Anaesth 2006;23(suppl 37):85. 